\title{
Developing a Conceptual Model for Examining the Relationship between Behavioural Antecedents of Supply Chain Collaboration, Integration and Performance
}

\section{Christos S. Tsanos}

Transportation System and Logistics Laboratory (TRANSLOG), Department of Management Science and Technology, Athens University of Economics and Business, Athens, Greece

Konstantinos G. Zografos

Lancaster University Management School, Lancaster, United Kingdom

\author{
Alan Harrison \\ School of Management, Cranfield University, Cranfield, United Kingdom
}

The International Journal of Logistics Management, Vol. 25, Issue 3, pp. 418 - 462. 


\title{
Developing a Conceptual Model for Examining the Supply Chain Relationships between Behavioural Antecedents of Collaboration, Integration and Performance
}

\begin{abstract}
Purpose: The objective of this paper is threefold: i) review the literature on the topic of behavioural antecedents of collaboration and their impact on supply chain integration and performance, ii) lay the theoretical foundations and develop a conceptual model linking behavioural antecedents of collaboration, information integration, coordination of operational decisions and supply chain performance, and iii) set out operationalisation considerations.

Design/methodology: A conceptual model with theoretical basis on Relational Exchange Theory (RET) and extant supply chain theory is developed as a causal model that can be operationalised using Structural Equations Modelling (Partial Least Squares) and a 'single key informant' approach.

Findings: Positive relationships between behavioural antecedents of collaboration (trust, commitment, mutuality/reciprocity), information integration, coordination of operational decisions and supply chain performance (efficiency, effectiveness) are hypothesised. RET provides adequate theoretical background that leads to the theoretical establishment of hypotheses between behavioural antecedents, supply chain integration and performance, which are worth testing empirically.

Research limitations/implications: The ideas presented in this paper enrich the study of behavioural factors in supply chain management and their impact on supply chain performance, and may benefit researchers in the field. The paper also sets the scene (experimental design, measurement items) for the upcoming field research. The empirical part of the work will provide the necessary evidence for the validation of the established hypotheses.

Practical implications: The proposed linkages may stimulate the interest of supply chain strategists towards more collaborative relationship management and affect their decisions on the behavioural antecedents of relationship formation and management. Moreover, the proposed model may help clarify how the integration of critical operational contingencies - information, operational decisions - can help achieve superior supply chain performance.

Originality/value: The paper establishes a causal relationship between constructs which have not been researched (mutuality/reciprocity, coordination of operational decisions) or have been researched individually or in combination (impact of integration on performance, impact of collaboration on performance) but not in the proposed integrated way. It also addresses the challenge of lack of theoretical justification on the development of knowledge that will assist decision making in SCM/logistics and its integration into models, processes and tasks. Finally, by using RET in selecting of behavioural factors and establishing hypotheses, it adds to the body of knowledge concerning the use of interorganisational theories in supply chain relationships.
\end{abstract}

Keywords: Integration, performance measurement, collaboration, relationship management

Article type: Conceptual paper 


\section{Introduction and purpose of the research}

It has been proposed that formation and management of collaborative relationships among supply chain partners lead to improved levels of integration and performance. For example, Min et al (2005) found that positive outcomes of collaboration included enhancements to efficiency, effectiveness and market position. In turn, it can be argued that managing collaborative relationships between supply chain partners (i.e., relationships in which 'two or more companies [share] the responsibility of exchanging common planning, management, execution, and performance measurement information') (Min et al, 2005; p. 237) requires the presence of behavioural antecedents that constitute building blocks binding partners together in such relationships.

However, it appears that the link between integration and performance is not fully established. Thus, more research on how to achieve integration is called for, as a response to ambivalent results on the impact of supply chain integration on performance (Fabbe-Costes and Jahre, 2008). Integration appears to require appropriate organisational and operational conditions in order to have a positive effect on performance. The behavioural antecedents of collaboration constitute an intuitively appealing set of conditions for achieving higher integration that has not been examined extensively in practice. For example, Tokar (2010: p. 89) observes that 'little research published in logistics and SCM journals focuses on developing knowledge concerning human behaviour, judgement and decision making and integrating that knowledge into models, processes and tasks'. Moreover, van der Vaart and van Donk (2008) suggest that the examination of the distinctive roles of attitudes (i.e., factors referring to the behaviour of supply chain partners in their relationships), patterns (i.e., interaction patterns between the focal firm and its supply chain partners) and practices (i.e., activities or technologies that affect collaboration of a focal firm with its suppliers and customers) in supply chain integration and the interrelationships between these categories of characteristics would be interesting.

Many behavioural factors have been suggested as antecedents of collaboration among partners. Our literature review revealed a multitude of concepts examined as behavioural factors. The challenge of theoretically justifying which factors to use in empirical research is often encountered. This selection does not follow an established pattern in this emerging area of research. We propose that behavioural antecedents are selected from the context of the more widely established theory of inter-organisational relationships. The research scope would thus be widened, increasing the explanatory character of the findings.

A number of different definitions for supply chain integration (for example, van der Vaart and van Donk, 2008; Chen et al, 2009) and performance (Fabbe-Costes and Jahre, 2008) have been proposed, yet variations in these definitions make comparisons of results difficult. It is not adequate to compare results on the relation between supply chain integration and performance without comparing the actual variables and metrics that have been used for assessing the constructs. We have followed Chen et al (2009) in considering supply chain integration as the integration of physical and information flows for creating seamless business processes and eliminating redundant activities across the supply chain. In particular, this definition encompasses key operations planning and control (OPC) processes, and the accompanying information exchange among partners. We also identify performance in the context of efficiency and effectiveness (Caplice and Sheffi, 1994; 1995) and utilise metrics that aim to capture performance at supply chain level rather than firm level. Based on our definitions of integration and performance and on the reviewed literature, we identify a research gap in addressing the relationship between the coordination of key OPC processes and the integration of required information exchange on the efficiency and 
effectiveness of supply chain-wide operations. The assessment of the latter is an issue that has not as yet received much attention (Fabbe-Costes and Jahre, 2008).

The above observations motivated us to expand our earlier research on the relationship between supply chain integration and performance (authors, 2008) by developing a conceptual model that considers a set of behavioural antecedents of collaboration and their impact on two factors:

- integration of key operations planning and control processes and accompanying information integration among partners,

- $\quad$ supply chain-wide performance, measured as efficiency and effectiveness.

A model which links behavioural antecedents of collaboration with supply chain integration and supply chain performance is a potentially fresh contribution.

The aim of this paper is to perform a review of the literature linking behavioural factors, supply chain integration and performance and, based on the selection of an appropriate interorganisational theory, to develop an integrated framework that will be combined into a unified model to further study how relationships among supply chain partners influence supply chain performance. Our paper is structured as follows. Section 2 presents the results of our literature review, describes the theoretical underpinnings of our conceptual model and defines behavioural antecedents, supply chain integration and supply chain performance. Section 3 discusses our research hypotheses which link the three constructs. Section 4 presents our research methodology in terms of method of analysis, survey design and selection of variables and metrics. Finally, Section 5 concludes our paper.

\section{Conceptualising behavioural factors, supply chain integration and supply chain performance}

We have performed an extensive review of the literature investigating linkages between behavioural factors, supply chain integration and/or supply chain performance, focusing on relationships among supply chain partners. In this respect, we focused on papers published between 2001 and 2011 in six major academic journals in the field of logistics and supply chain management (International Journal of Logistics Management, International Journal of Logistics: Research and Applications, Supply Chain Management: International Journal, Journal of Business Logistics, Journal of Supply Chain Management and International Journal of Physical Distribution and Logistics Management), six journals in the field of operations management (Journal of Operations Management, Production and Operations Management, International Journal of Operations and Production Management, Manufacturing and Service Operations Management, International Journal of Production Research, International Journal of Production Economics) and four journals in the field of performance measurement (Journal of Productivity Analysis, Benchmarking: An International Journal, International Journal of Productivity and Performance Management, International Journal of Business Performance Management). Additional search using the Google Scholar database was performed to identify relevant papers published in other academic journals. The main keywords used in this search were "integration" and "performance", while "trust", "commitment", "alignment", "behavioural factors" and other keywords were used to filter the results of the above search. On the basis of this initial broad search, over 200 papers were collected. These papers were then reviewed in detail to identify those investigating relationships between behaviour of supply chain partners, dimensions of integration/collaboration and (firm or supply chain-wide) performance. The findings of the papers that were considered relevant are summarised in Table 1. 
Insert Table 1 here

This review has yielded the following observations:

(1) Performance is mostly focused on the focal firm, (e.g., Moberg et al, 2004; Flynn et al, 2010; Henrandez-Espallardo et al, 2010) and suppliers (e.g., Duffy and Fearne, 2004; Ha et al, 2011; Sanders et al, 2011; van der Vaart et al, 2012). This is also asserted by van der Vaart and van Donk (2008) in their critical review of survey-based research on supply chain integration and performance. Yet, the shift of the focus of competition from focal firms to supply chain systems increases the importance of supply chain-wide performance and thus the selection of metrics assessing performance across the supply chain. We therefore sought to identify such measures and include them in our framework.

(2) Operational performance (e.g., Ryu et al, 2009; Zacharia et al, 2009; Flynn et al, 2010; Nyaga et al, 2010,), cost/financial performance (e.g., Zacharia et al, 2009; Kim and Narasimhan, 2002; Flynn et al, 2010; Lado et al, 2011) and combinations thereof (e.g., Panayides and Lun, 2009) are the focus of performance measurement. We believe that linking supply chain integration to financial performance misses out on the crucial aspect of operational success, which, in turn, leads to improved financial performance; the examination of the direct link between supply chain integration and financial performance is also questioned by van der Vaart and van Donk (2008). We therefore sought to include measures of operational performance in our framework.

(3) The concepts of supply chain integration are quite diverse: for example, they incorporate elements of operational collaboration (e.g., joint responsibility, shared planning), information exchange (e.g., Paulraj et al, 2008, Hung et al, 2011) or cross-functional orientation (e.g., Eng, 2005). Few studies (e.g., Petersen et al, 2005; Kim and Narasimhan, 2002; Kotzab et al, 2011) select a broader view of integration with customers and suppliers. We decided to interpret 'integration' in terms of the basic supply chain flows (materials and information) and the coordination of the operational decisions required to manage them, both between focal firm and its suppliers and between focal firm and its customers.

(4) The most common behavioural factors are trust and commitment. Other elements proposed suggested as behavioural factors include joint attempt to achieve individual and mutual goals (Eng, 2005), mutual cooperation in differences (Hernandez-Espallardo et al, 2011), relational capabilities of the supply chain (Lado et al, 2011), satisfaction (Nyaga and Whipple, 2011), power (Wu et al, 2004). However, additional factors which merit research (notably mutuality/reciprocity, which play a fundamental role in shaping the operation of a relationship) are not examined.

The examination of relationships among supply chain partners requires the study of governance mechanisms in inter-firm exchanges and the selection of an appropriate theoretical foundation to study them. Inter-firm exchanges can take different forms, distinguished by several key dimensions such as duration and continuity, and may span a continuum from discrete (or market-based) to relational (Anderson and Narus, 1990; Fontenot and Wilson, 1997; Ring and van de Ven, 1992). Discrete exchanges constitute 'relatively short-term bargaining relationships between buyers and sellers designed to facilitate an economically efficient transfer of property rights' (Ring and van de Ven, 1992: p. 485), exclude any relational elements between the involved parties, and are characterised by limited communication (Dwyer 
et al, 1987). Relational exchanges are characterised by their duration over time, and involve long-term investments that stem from recurring transactions related to the production and transfer of property rights among the involved parties. Using the approach of Ring and van de Ven (1992), our classification of supply chain relationships into one of the proposed forms of inter-firm exchange, shown in Table 2, suggests that such relationships are most closely associated with relational contracting transactions and are best approached by means of Relational Exchange Theory (RET).

Table 2 here

RET has been described as a critical foundation for understanding and interpreting behavioural dynamics in exchange relationships (Joshi and Stump, 1999). When value-added partnerships are developed between organisations, each makes substantial investments in developing a long-term collaborative effort and a common orientation towards individual and mutual goals (Fontenot and Wilson, 1997). RET investigates the behavioural characteristics influencing the development of such relationships and the factors necessary for maintaining them (Morgan and Hunt, 1994). If supply chain integration is viewed as the linkage of business functions and processes within and across companies into a highperforming business model (Chen et al, 2009), the opportunity exists to use RET to examine the influence of behavioural antecedents of collaboration on supply chain integration.

Other theoretical approaches have been employed to study the mechanisms governing the formation of exchange relationships, such as power-conflict theory (Gaski, 1994), resource-based view (Barney, 1991), social exchange theory (Emerson, 1976), dependence balancing theory (Heide and John, 1990) and Transaction Cost Analysis (TCA), with the latter being the most prominent (Heide and John, 1992). The usefulness of TCA stems from the fact that it can explicitly identify conditions under which different structural arrangements are appropriate and can provide insight into the comparative mechanisms for structuring exchange relationships (Heide and John, 1992). However, studies based on TCA tend to view opportunism and cost minimisation as the driving force behind the formation of exchanges among partners (Lambe et al, 2001). It is doubtful if these are the only driving forces prompting organisations to take such actions, as human behaviour demonstrates characteristics that deviate significantly from the assumption of opportunism (Heide and John, 1992). Therefore we consider RET to be more appropriate than TCA in providing the opportunity to take a broader view of behavioural antecedents of supply chain integration. We review these next, followed by a closer examination of the concepts of supply chain integration and performance.

\subsection{Behavioural antecedents}

Collaboration among supply chain partners is positively affected by several characteristics of the behaviour that partners are expected to demonstrate in establishing and managing collaborative relationships. In our literature review, we identified four factors that are recurrently mentioned as antecedents of collaboration: trust, commitment, mutuality and reciprocity. We selected these factors to include in our conceptual model and justified their inclusion under RET, providing a broader perspective by including two behavioural antecedents (mutuality and reciprocity) that have not been examined in the context of supply relationships thus far. 
2.1.1 Trust: is seen in RET as the cornerstone of strategic partnerships and the foundation of collaborative behaviour between organisations (Morgan and Hunt, 1994; Doney and Cannon, 1997). Trust enables collaborating organisations to focus on the long-term benefits of entering a relationship (enhance competitiveness, reduce transaction costs). In mixed and idiosyncratic investments with repeated transactions (supply chain relationships), trust enables partners to relax their concerns about potential negative implications of their choices due to their bounded rationality (Ring and van de Ven, 1992). This also means that relations characterised by trust are expected to survive greater stress and display greater adaptability (Williamson, 1985).

2.1.2 Commitment: is defined as the belief of a partner that the exchange is so important it merits the maximum effort to maintain it (Morgan and Hunt, 1994). In relationships characterised by commitment, partners have achieved a level of satisfaction from the exchange process that precludes the consideration of other partners that can provide similar benefits (Dwyer et al, 1987). Commitment constitutes a valuable asset that exchange partners attempt to develop and maintain in their relationships (Morgan and Hunt, 1994). The limited empirical research of commitment in supply chain relationships suggests a positive relationship between commitment and integration of supply chain business processes (Zhao et al, 2008) and between organisational commitment and supply chain governance mechanisms (Fawcett et al, 2006).

2.1.3 Relationship between trust and commitment: approaches based on RET suggest and empirically validate that the level of trust in a relationship has a positive impact on commitment. Indeed, Morgan and Hunt (1994) in their seminal paper on the theory of trust-commitment in relationship marketing provide conclusive evidence of high correlation between trust and commitment. Kwon and Suh (2005) support the hypothesis of Morgan and Hunt (1994) in a supply chain context. The theoretical pairing between trust and commitment is based on the concept of generalised reciprocity according to which 'mistrust breeds mistrust' and directs partners to more short-term exchanges (Morgan and Hunt, 1994). This shows that complicated pairings of concepts exist, involving most of the behavioural factors we include in our model.

2.1.4 Mutuality/Reciprocity: Mutuality is defined as the 'belief about the inherent value of cooperating for mutual gain' (Campbell, 1997: p. 1). Strong expectations of mutuality of interest will lead to cooperation required for maintaining a long-term relationship, especially in relationships where transfer of property rights among legally equal and free parties is involved. When partners enter a relational exchange, they commit assets in an idiosyncratic investment and agree (implicitly or explicitly) on the division of the benefits and costs of their relationship, thus entering a "mutual hostage position" (Campbell, 1997). This creates incentives for both to work hard towards maintaining this relationship. Reciprocity is the degree to which individuals expect cooperative action (as opposed to forced interaction) within a relationship, and constitutes a major factor in the formation of inter-organisational relationships (Oliver, 1990). Exchange partners anticipate that the long-term benefits from such a relationship will outweigh disadvantages (e.g., partial loss of decision-making authority) and that accrued benefits will be distributed in a fair manner (Dwyer et al, 1987). This type of relationship assumes reciprocal interdependence, where the output produced by each of the partners constitutes input for the other (Thompson, 1967). Relationships characterised by reciprocal interdependence are fundamentally complicated and unpredictable and are best coordinated by mutual adjustment (Thompson, 1967). The desire for control and the reluctance to relinquish control may reflect power, influence or conflict perspectives in the formation of reciprocal 
relationships (Oliver, 1990); however a considerable amount of the literature on inter-organisational relationships assumes that the process of formation of symmetric relational exchanges is characterised by balance and equity instead of coercion and conflict (Oliver, 1990). In such relationships, reciprocity is the manifestation of the anticipations of partners towards a beneficial and fair relationship.

Research on mutuality and reciprocity in supply chain relationships is scarce. Mutuality is limited to its listing as an enabling factor (Handfield and Bechtel, 2002; Simatupang and Sridharan, 2002), while Ivens (2005) examines its effect on the flexibility of service providers in industrial service relationships. Koulikoff-Souviron and Harrison (2006) cite evidence of reciprocity in a case study on inter-firm supply chain relationships. No research output on the effect of mutuality or reciprocity on supply chain integration has been encountered; indeed, the latter is considered as a relational norm that requires further study in a supply chain context (Hammervoll, 2009).

\subsection{Supply Chain Integration}

Integration in a broader organisational sense has been defined by Lawrence and Lorsch (1986: p. 67) as 'the quality of the state of collaboration that exists among departments that are required to achieve unity of effort by the demands of the environment'. Building on the two basic blocks of this definition collaboration among units and a common goal - extant definitions of supply chain integration highlight various aspects such as the combination of inward and outward-facing integration (Frohlich and Westbrook, 2001), the coordination across operational activities and resources (Hertz, 2001) and the integration of relationships across partners (Kim and Narasimhan, 2002). Such variety of definitions suggests a lack of a clear delineation of the concept, something which Chen et al (2009) have attempted to rectify by proposing the concept of supply chain process integration. They define supply chain process integration as a set of continuous restructuring activities, aimed at seamlessly linking relevant business processes and reducing redundant processes within and across firms. Thus, integration has an internal and an external perspective and focuses on business processes, while its main goals are cost savings (cost orientation) and improved customer service level (customer orientation).

Our definition of supply chain integration follows this conceptualisation and highlights the integration of physical and information flows for creating seamless business processes and eliminating redundant activities across the supply chain. The integration of information flows across supply chain partners is labelled 'information integration', while the integration of physical flows is represented by the coordination of decision-making among partners on operational processes and is labelled 'coordination of operational decisions'. Coordination is defined after Quinn and Dutton (2005: p. 1) as 'the process people use to create, adapt and re-create [supply chain] organisations'. The selection of the operational processes is based on the Operations Planning and Control (OPC) framework proposed by Vollmann et al (2005); they constitute fundamental supply chain management processes (Lambert and Cooper, 2000). Finally, the cost orientation and customer orientation of the supply chain are examined in our model as performance outcomes of integration (efficiency and effectiveness respectively). The supply chain integration dimensions and variables are depicted in Table 3 and are further described below.

Table 3 here

\subsubsection{Information integration}


Information integration is a consistent factor in the supply chain integration literature and practice. Its importance in the success of supply chain collaboration has been highlighted since the implementation of the first collaboration initiatives such as Efficient Consumer Response (Whipple and Russell, 2007). Its role is to allow timely and accurate flow of information across the supply chain and facilitate coordination of operational decision-making among partners. In this respect, visibility and timeliness of information constitute critical properties for efficient information flow. Information visibility constitutes an essential criterion for the long-term competitiveness of the supply network (Bartlett et al, 2007) and is defined as the ability of partners to have access to information related to operations across the supply chain and entails 'sharing critical data required to manage the flow of products, services, and information in real time between customers and suppliers (Handfield et al, 2004: p. 3). Information timeliness is the availability of information to supply chain partners in a timely manner, precluding inaccuracy and obsolescence.

It should be stated at this point that Relational Exchange Theory treats information sharing either as a direct antecedent or as a factor affected by the behavioural antecedents of collaboration. The first approach suggests that information sharing by one exchange partner is a signal of good faith to the other by providing tangible evidence that the former is willing to make itself vulnerable to the latter in order to demonstrate its benevolent motives towards the formation and management of a relational exchange (Doney and Cannon, 1997), thus reducing the degree of behavioural uncertainty among partners and indirectly improving the level of trust and commitment in the relational exchange. The second approach suggests that information sharing among partners in a relational exchange requires the presence of antecedents such as trust, commitment and mutuality. Trust facilitates the sharing of information by reducing the risk associated with opportunistic behaviour (Seppanen et al, 2007) and encourages greater information sharing between the relational exchange partners (Premkumar et al, 2005). The detrimental effect of lack of trust on information exchange is supported by a number of authors in the interorganisational relationship domain (Anderson and Narus, 1990; Mohr and Spekman, 1994). We follow the second approach, viewing information sharing as an enabler for higher performance assisted by the presence of favourable behavioural conditions.

\subsubsection{Coordination of operational decisions}

The coordination of operational decisions refers to the coordination of operations planning and control (OPC) activities across the supply chain. We employ the widely used OPC framework proposed by Vollmann et al (2005), which involves activities for general direction setting (demand management, sales and operations planning, resource planning) and activities for detailed material and capacity planning, which are executed by the associated OPC execution systems (shop-floor systems, supplier systems).

Following the above classification, the coordination of the activities which comprise the "demand side" of an OPC system (i.e., demand-driven activities) involves cooperation among partners in demand management (demand forecasting, inventory management and replenishment and determination of customer service levels) and in sales and operations planning (the development and update of the sales and operations plan, and the decisions on production volume and mix). The coordination of the "supply side" activities (i.e., activities related to the supply of products) includes resource planning (cooperation among partners in supply chain event management, performance assessment and collaborative replenishment planning), coordination of material planning (joint decision-making on lot sizing, safety stock levels, 
safety lead times and demand for service parts) and coordination of capacity planning (planning of capacity requirements and capacity allocation across supply chain partners).

\subsection{Supply Chain Performance}

Research on the conceptualisation of supply chain performance encompasses a variety of metrics, such as financial and operational performance (Gunasekaran et al, 2004), customer service, cost management, quality, productivity and asset management (Closs and Mollenkopf, 2004). Diverse definitions and constructs for supply chain performance exist and different metrics have been used for assessing similar dimensions. Metrics are often based on the focal firm, and 'supply chain' metrics are at company level rather than supply chain level.

We view supply chain performance as the efficiency and effectiveness of supply chain operations (Caplice and Sheffi, 1994; 1995). These dimensions represent the internal outcome of supply chain operations (efficiency) and the external outcome perceived by the end-customer (effectiveness). This view is in line with the supply chain process integration concept proposed by Chen et al (2009), which examines whether integration - driven by supply chain cost and customer-orientation - actually delivers positive results in both of these performance dimensions. Efficiency represents the supply chain's ability to provide a given level of end-customer service at low cost with high levels of accuracy in matching production with actual demand. Effectiveness represents the supply chain's ability to deliver according to end-customer requirements and pre-specified service standards (Neely et al, 1996).

In selecting metrics for assessing supply-chain wide performance, we are faced with a number of constraints:

i) the metrics should be commonly used by supply chains

ii) the metrics should represent performance across the supply chain

iii) values of the metrics can be provided by a focal firm as proxy for the supply chain

iv) respondents are willing to provide values for the selected metrics

v) respondents can report objective values or (if the objective values cannot be revealed) base their subjective responses on objective data.

Literature reviews on the development of supply chain performance measurement systems (e.g., Gunasekaran et al, 2001; Gunasekaran et al, 2004; Shepherd and Günther, 2006; Cuthbertson and Piotrowicz, 2011) report the use of a wide variety of performance measures under various categorisations, e.g., as strategic, operational and tactical, financial and non-financial, and according to SCOR supply chain processes. The difference between studies aimed at developing performance measurement systems for supply chains and studies that require supply chain performance to be reported (such as the present) is that the latter must consider widely-used supply chain-wide performance metrics that are most likely to be measured by the surveyed supply chains, so as to reduce non-response due to lack of assessment of the selected performance metrics. Furthermore, the sensitive character of supply chain performance may preclude potential participants from responding when faced with an extensive list of detailed questions on performance. Thus, in studies such as the present, whose objective is not to provide a detailed assessment of the performance of the logistical activities of a company but rather to associate supply chain integration with supply chain performance at a strategic level, it is preferable to select a small number of popular supply chain-wide performance metrics for which respondents are able and willing to provide a subjective or objective assessment. 
Given the above constraints and considerations, we selected the four performance metrics presented in Table 4.

Table 4 here

The justification of the selection of these performance metrics is subjective to a significant extent, as there is little evidence on the relative importance and popularity of supply chain performance metrics in the relevant literature. For example, Gunasekaran et al (2004) develop rankings of some strategic and operational metrics based on a survey of 21 companies; the majority of the metrics refers to specific supply chain processes (e.g., order planning, supplier performance, delivery). Therefore, a degree of subjectivity is present in this decision.

Two metrics for assessing supply chain efficiency are selected: supply chain cycle efficiency, which assesses the use of the supply chain cycle time for value-adding activities, and supply chain flexibility, which assesses the time required for the supply chain to respond to an unplanned increase in demand without service or cost penalty. These two metrics can pinpoint where efficiency gains can be realised and assess how flexible is the supply chain in responding to external influences. A high degree of supply chain cycle efficiency reduces idle time in the supply chain and decreases supply chain costs by achieving higher utilisation of supply chain capacity and resources, while a high degree of flexibility allows the supply chain to continue providing a given level of end customer service even under irregular circumstances. We believe that these two metrics sufficiently represent the concept of efficiency in the supply chain.

Supply chain effectiveness is assessed through the measurement of order fulfilment lead time, which assesses the time between order entry and order delivery, and perfect order fulfilment, which assesses the ratio of perfectly completed orders over the total number of orders places. These two metrics constitute basic SCOR Key Performance Indicators (Supply Chain Council, 2010) assessing the attributes of supply chain responsiveness and reliability respectively. Order fulfilment performance is very important, as the order fulfilment process may constitute the only interaction between the customer and the firm and determine the customer's experience and service level (Croxton, 2003). Moreover, it requires communication and coordination with functional areas within the firm and with suppliers and customers to develop processes that meet customer requirements in a cost effective way (Croxton, 2003). We believe that these two strategic order fulfilment performance metrics (order fulfilment lead time, perfect order fulfilment) capture the essence of customer satisfaction and sufficiently represent the concept of effectiveness in the supply chain.

We now put these concepts together and develop our model and associated research hypotheses.

\section{Research Hypotheses and Model Development}

Pulling together the above concepts of behavioural antecedents, supply chain integration and performance, we next consider the key features of each, the development of research hypotheses, and how they can be put together in a model that enables the investigation of their proposed linkages.

Figure 1 here 
In Section 2.1 above, we suggest that collaboration among supply chain partners is affected by behavioural antecedents that partners are expected to demonstrate when establishing and managing collaborative relationships. We suggest that these antecedents do not appear independently of each other, but that causal relationships exist between them. We elaborate on these relationships in hypotheses $\mathrm{H} 1$ to H3.

Mutuality and reciprocity play a fundamental role in shaping the operation of a relationship and constitute a basic condition for the development of a relationship contract between partners in a similar manner that they may constitute the basis of a psychological contract in general (Dabos and Rousseau, 2004). The agreement of supply chain partners on the specific mutual terms and reciprocal conditions of their relationship may increase trust, as it enables partners to relax their concerns about potential negative implications of their choices due to their bounded rationality (Ring and van de Ven, 1992) and focus on the long-term benefits of the relationship. Thus, when mutuality and reciprocity are ensured in the formation of a supply chain relationship, the partners involved can trust each other that they will not act detrimentally towards the relationship (e.g., contract violation, breach of contract). Said differently:

Hypothesis 1 (H1): The higher the level of mutuality and reciprocity in a relationship between supply chain partners, the higher level of trust among partners

According to the commitment-trust theory (Morgan and Hunt, 1994), supply chain partners commit themselves to relationships with other trustful partners, because 'commitment entails vulnerability' and they hence feel the need to trust other partners in order to reduce vulnerability. Trust influences commitment due to generalised reciprocity, according to which 'mistrust breeds mistrust', making supply chain partners turn to more short-term exchanges (Morgan and Hunt, 1994) with smaller degree of commitment. When trust exists in a relationship, partners consider it so important that it warrants the highest effort possible for maintaining it. Thus, in order to consummate commitment in a relationship, trust must be present among partners. Said differently:

Hypothesis 2 (H2): The higher the level of trust in the relationship among supply chain partners, the higher the level of relationship commitment.

The presence of commitment in a supply chain relationship presupposes that partners accept each other's motives as positive and that they will not be used in adversarial ways. Given the risk inherent in the exchange of information on business processes and operations that may be highly proprietary, partners' commitment to the relationship is necessary to ensure the security of information exchange (Daugherty et al, 2002). Commitment ensures that the partners will not bear the risk of undermining the relationship performance by exchanging inaccurate or obsolete information. Said differently:

Hypothesis 3 (H3): The higher the level of commitment in the relationship among supply chain partners, the higher the degree of information integration among partners

Supply chain theory suggests that information integration can bring significant operational benefits for the supply chain. When accurate information is made visible throughout the supply chain in a timely manner, operational benefits such as reduced cycle time, improved tracing and tracking of 
materials and products, reduced transaction costs and enhanced customer service can occur (Bagchi and Skjøett-Larsen, 2005). In Section 2.2, we explained how we came to define supply chain integration by incorporating the integration of physical and information flows for creating seamless business processes and eliminating redundant activities across the supply chain.

The visibility of accurate and timely demand and inventory information to partners across the supply chain facilitates the coordination of production activities by taking into account end-customer demand, the demand of downstream partners and their inventory levels and usage rates. It also leads to improved coordination of resource planning in supply chain tiers, and in materials planning within and across tiers. In turn, coordination in operations planning facilitates coordination of decision-making on medium- and long-term supply chain capacity planning as it is based on actual production requirements instead of requirements based on demand forecasts. Moreover, visibility of actual demand information in different supply chain tiers can enhance production planning efficiency (McCarthy and Golicic, 2002). The above discussion suggests that information integration has a positive impact on the coordination of operational decisions that are related both to the demand side as well as the supply side of the OPC system. Said differently:

Hypothesis 4 (H4): The higher the degree of accurate and timely exchange of supply chain information, the higher the degree of coordination of decisions related to the demand side of the OPC system

Hypothesis 5 (H5): The higher the degree of accurate and timely exchange of supply chain information, the higher the degree of coordination of decisions related to the supply side of the OPC system

The coordination of demand management involves all activities that place demand on manufacturing capacity, while the coordination of sales and operations planning translates the sales/marketing plan into requirements for production resources (Vollmann et al, 2005). In essence, demand management activities determine the overall demand for manufacturing output, while sales and operations planning activities constitute the aggregated version of the master production schedule. Thus, the coordination of these two "demand side" categories of activities affects the coordination of supply side activities related to actual production, i.e., resource planning, materials planning and capacity planning. Said differently:

Hypothesis 6 (H6): The higher the degree of coordination of decisions related to the demand side of the OPC system, the higher the degree of coordination of decisions related to the supply side of the OPC system.

Coordinated demand management enables supply chain partners to develop accurate forecasts of customer demand and short- and medium-term capacity requirements and allows them to anticipate potential changes in demand. It may lead not only to increased reliability in order fulfilment (i.e., lower order fulfilment lead times, higher perfect order fulfilment rates) but to higher utilisation of supply chain resources as well. This is due to the improved insight on end customer demand, which allows partners to 
better plan production activities and to estimate and allocate the required production capacity on the basis of actual end customer demand.

Coordination in logistics management through sales and operations planning, resource planning and materials planning (Vollman et al, 2005) leads to higher supply chain cycle efficiency. This can be measured by the ratio of total value-adding time to total time that a product spends in the supply chain, because planning and scheduling of operations according to actual end-customer demand reduces the need for overproduction, and reduces order fulfilment lead times. Coordinated logistics management can thus increase supply chain flexibility, as the reduction of waste may lead to a reconfiguration of the supply chain that increases its capability to respond to unplanned requirements for higher output. Coordination also improves the balance between demand and supply, which has fundamental impacts on the efficiency and effectiveness of supply chain operations (Vollmann et al, 2005); when demand exceeds supply, customer service (order fulfilment lead time, perfect order fulfilment) suffers because manufacturing cannot deliver the products required by the customers. On the other hand, when supply exceeds demand, inventories within the supply chain increase, leading to reduced supply chain efficiency and reduction of production rates. Said differently:

Hypothesis 7 (H7): The higher the degree of coordination of operational decisions related to the demand side of the OPC system, the higher the supply chain performance

Hypothesis 8 (H8): The higher the degree of coordination of operational decisions related to the supply side of the OPC system, the higher the supply chain performance

In Section 4, we propose how this model could be operationalised from a research perspective.

\section{Research Methodology}

\subsection{Modelling with Partial Least Squares}

Our research model suggests relationships among a set of latent theoretical constructs which are measured with the use of multiple observed measures. The existence of multiple relationships among latent variables that are indirectly inferred from manifest variables justifies the use of a structural equations modelling (SEM) approach for testing the proposed model.

Covariance-based SEM constitutes the dominant structural equations modelling technique (Chin and Newsted, 1999) but its use presents a number of inherent restrictions. Specifically, covariance structure analysis typically requires reflective as opposed to formative indicators (Chin and Newsted, 1999) and its use suggests the existence of relevant theory and the objective of theory testing rather than theory building (Chin, 1995). In terms of sample size, the use of covariance-based SEM with a small sample size may lead to poor parameter estimates and model test statistics or even a Type II error. Various

lower bounds on sample size are recommended, suggesting samples of 200 or more responses for complex models (Hulland et al, 1996). On the other hand, the variance-based Partial Least Squares (PLS) methodology shifts the focus from confirmatory theory testing to predictive research models in which the emphasis may be more on theory development than confirmation (Barclay et al, 1995) and the conceptual model and associated measures are newly or not well developed (Chin, 1995). Moreover, PLS poses 
limited demands in terms of sample size (Chin and Newsted, 1999) and is considered more efficient in the estimation of large-scale models than covariance-based SEM (Chin, 1995).

Our model - which sets out to investigate all of the relationships between supply chain collaboration, integration and performance - is a potentially new proposition. While some of its dimensions have been identified in research on supply chain collaboration and integration (such as trust and commitment, information integration, efficiency and effectiveness), others (such as mutuality, reciprocity) have not been examined. New multi-dimensional indicators and measurement scales have been developed for information integration and coordination of operational decisions. This inclines our model toward theory development than confirmation, and thus we consider PLS as more suitable in the present exploratory research setting.

\subsection{Survey approach}

Different supply chain partners have different perceptions of the importance of the elements preceding integration and their importance in determining supply chain performance. There is theoretical and empirical justification on the implementation of a 'single key informant approach' (Zacharia et al, 2009) using proxy-reports (Menon et al, 1995) from one respondent (i.e., focal firm) about the behaviour and attitudes of other respondents (upstream and downstream partners). At the outset, the presence of (episodic and semantic) information available to respondents regarding the behaviour of their partners assists judgment formulation in a proxy-report and increases convergence between self- and proxy-reports (Menon et al, 1995). Moreover, the knowledgeability requirement (Anderson and Weitz, 1992) suggests that accurate data about organisational properties can be provided by knowledgeable informants. This is clearly the case in a supply chain in which focal firms have information about the relationships with their suppliers and customers and knowledge about the degree of integration and performance of the supply chain. This may also reduce the bias caused by the non-consideration of the opinions of upstream and downstream partners. In addition, given that respondents provide information which is based on revealed (as opposed to perceived) behaviours and that the focal firms are companies operating international supply chains, they are inclined to have a broader cultural perspective in their answers. Finally, the selection of a dyad or triad of respondents increases the time and cost associated with the collection of the required information as three independent respondents must coordinate to provide one valid set of responses; indeed the difficulty of obtaining data from dyads is verified in a multitude of studies using proxy-reports (e.g., Anderson and Weitz, 1992; Noordewier et al, 1999; Lambe et al, 2002; Zacharia et al, 2009).

The provision of meaningful responses for our survey requires a holistic view of supply chain operations and the relevant information is most commonly and easily available to the focal firm. In addition, this research focuses on obtaining a broad understanding of the behavioural factors driving supply chain integration and affecting supply chain performance. While cultural differences among international supply chain partners could affect the perception of partners on the degree of presence of certain behavioural factors in their supply chain relationships, we believe that the fulfilment of the knowledgeability principle, coupled with the assumption of response honesty, can provide responses that are not far from reality. For all the above reasons we have decided to employ the single key informant approach.

The concepts and measures included in the model were selected by extensively reviewing the literature in each research field (antecedents of collaboration, supply chain integration, supply chain 
performance) and using RET and supply chain theory to justify their selection. A survey instrument was developed, including 102 questions assessing the behavioural antecedents, and the supply chain integration and performance dimensions described earlier in the paper. The items questioning the presence of the behavioural antecedents in the relationships between focal firm and major supplier / major customer were worded as statements with which the respondent was asked to provide their degree of agreement or disagreement. Respondents were also asked directly to provide a response on the degree of presence of the information integration dimensions and the performance of the supply chain with regards to the selected performance metrics based on the selected 5-point scale. The survey instrument was pre-tested by five logistics managers and six academic researchers who were asked to provide comments on the wording, presentation and face validity of the items and on the overall structure of the survey instrument, as well as the appropriateness of the selected supply chain performance measures. Suggestions for rewording and increasing the clarity and comprehensiveness of the items were incorporated in the final version of the instrument. The survey design followed the Tailored Design Method (Dillman, 2007) with an initial contact and a series of follow-up contacts envisaged to be performed with the companies invited to participate in the survey.

Sample selection should reflect the definition of the study population. Strategic studies such as the present can be performed at national, regional and even global level, however restricting the sample to a specific country may compromise the generalisability of the results. Thus, the respondents (key informants) can be focal firms of a specific region (e.g., Europe, Asia, Americas) operating international supply chains. The sample can also be selected at global level, i.e., firms around the world operating international supply chains; this sample selection strategy may be meaningful for setting a baseline situation with which the results of the survey at regional and national level can be compared and potential cultural or regulatory differences can be identified. With regards to the industries involved, the sample should ensure adequate coverage of a broad spectrum of industrial sectors that may benefit from higher levels of supply chain integration. A review of existing empirical research on supply chain integration can help identify industrial sectors for which a high level of supply chain integration is both meaningful and beneficial. Such industrial sectors should be highly competitive, encompass a wide variety of products requiring many suppliers and catering to numerous customers, and strive for higher performance. Examples of manufacturing sectors demonstrating such characteristics are the automotive sector (Droge $e t$ al, 2004), food sector (van der Vaart and van Donk, 2008), fabricated metal products, machinery and equipment sectors (Frohlich and Westbrook, 2001), and mechanical, electronics and transportation equipment sectors (Danese et al, 2013).

\subsection{Variables and metrics}

Covariance-based SEM generally assumes that the indicators used to measure a latent variable are reflective in nature (Chin, 2010), i.e., the indicators are influenced by the underlying latent variable. The incorporation of formative indicators (i.e., indicators affecting the latent variable, also known as 'cause measures') in an SEM analysis may result in significant identification problems (Chin, 2010). In contrast, variance-based modelling approaches such as PLS can successfully incorporate formative indicators assuming that a latent variable with formative indicators is connected to at least one other construct to produce meaningful information (Chin, 2010). The constructs in our model explicitly incorporate formative indicators which are considered to produce/form/cause the latent variable; this is in line with the 
theoretical underpinnings of our model, further justifying the selection of PLS as the suitable modelling approach.

We measure trust after Ganesan (1994), who considers credibility and benevolence as its two building blocks. This conceptualisation has been empirically tested in the context of the development of long-term relationships between retailers and vendors. We propose to adapt this scale to the context of upstream supply chain relationships between focal firm and major upstream partner and downstream supply chain relationships between major downstream partner and focal firm. We propose to select 4 out of the 7 items for measuring credibility and 3 out of 5 items for measuring benevolence, on the basis of the applicability of these items in inter-organisational relationships between the focal firm and its major upstream and downstream partners. Hence, the measurement of trust includes seven items for assessing trust in the relationship between focal firm and major supplier and seven for assessing trust in the relationship between focal firm and major customer.

We propose to measure commitment using the widely-used three-dimensional conceptualisation of organisational commitment (Meyer and Allen, 1991). Of the three dimensions of commitment (affective, continuance, normative) we selected the first two as representative dimensions of commitment in a supply chain relationship context, which also seem to be the most relevant for inter-organisational relationships (Geyskens et al, 1996). Affective commitment prevents partners from abandoning a relationship if they are presented with higher financial rewards elsewhere, which may occur if extrinsic (financial) rewards constitute the sole source of motivation in a relationship. Continuance commitment precludes partners from leaving a relationship if relationship termination costs are higher than the potential benefits from the formation of an alternative relationship and if important conditions exist (e.g., a steady and profitable order schedule provided by the focal firm to an upstream supplier) that may be lost with the termination of a relationship (Meyer and Allen, 1991). We adapt measures of commitment from Allen and Meyer (1990) and Meyer and Allen (1991) to fit the context of supply chain relationships. The assessment of commitment includes seven items on the commitment in the relationship between focal firm and major supplier and seven on the commitment in the relationship between focal firm and major customer.

We propose to measure mutuality by Clemmer and Schneider (1996) and Ivens (2005), whose sixitem scale is the only readily available and empirically tested measurement scale and is used with slight contextual adaptations. The scale identifies three dimensions of mutuality: procedural justice (perceived fairness of the policies/procedures that guide the decision-making process in a relationship between two supply chain partners), distributive justice (perceived fairness of the outcome of the decision-making process in a relationship between two supply chain partners) and interactional justice (perceived fairness in the treatment of supply chain partners throughout the decision-making process in a relationship). Six items for assessing mutuality in the relationship between focal firm and major supplier and six for assessing mutuality in the relationship between focal firm and major customer are included. Finally, since no validated measurement items for reciprocity were encountered in the literature, we have developed a new scale composed of five items based on van Tilburg et al (1991) and Coyle-Shapiro and Kessler (2002), which identify three dimensions of reciprocity. These are equality of the obligations of two supply chain partners engaged in a relationship, equality in the degree of fulfilment of supply chain partners' obligations and equality of support provided by two supply chain partners engaged in a relationship. Five items for assessing reciprocity in the relationship between focal firm and major supplier and five for assessing reciprocity in the relationship between focal firm and major customer are included. 
We propose to measure information integration variables by developing five measurements based on our selected operational processes for each of the two variables (visibility and timeliness). For the measurement of coordination of operational decisions we developed four measures of coordination of demand management, two items for measuring coordination of sales and operations planning, three items for coordination of resource planning, four items for coordination of materials planning and two items for capacity planning. These measurements reflect Heide and John (1990), who measure the extent of joint activities between buyers and suppliers in industrial relationships, and Subramani and Venkatraman (2003), who measure joint decision making in asymmetric inter-organisational relationships.

We propose to measure research variables using a multiple point Likert ordinal scale. We selected a 5-point scale for the following reasons:

- It provides the legitimate option of neutral assessment, which if not provided (scale with even number of items) may introduce respondent bias by forcing respondents to select a more positive or negative response (Alwin and Krosnick, 1991).

- Differences in statistical properties (mean, skewness/kurtosis) between 5-point and 7-point Likert scales are minor (Dawes, 2008).

- A 5-point scale is less confusing for the survey participants and may encourage higher participation, thus yielding a higher response rate.

The research variables, measurement items and relevant scales included in the survey instrument are illustrated in Table 5.

Table 5 here

\subsection{Analysis and results reporting in Partial Least Squares}

Data analysis and reporting in covariance-based SEM (Maximum Likelihood and Generalised Least Squares) usually follows a two-step approach which involves an exploratory and a confirmatory analysis (Anderson and Gerbing, 1988). A similar process is suggested for PLS (Henseler, 2009; Chin, 2010), in which the first step evaluates the results of the measurement (outer) model and the second step evaluates the structural (inner) model results. At the outset, it is prudent to examine the data for normality (skewness/kurtosis), despite the fact that PLS does not assume a distributional form for the variables measured (Chin and Newsted, 1999) and therefore may not require a non-parametric normality test (e.g., Kolmogorov-Smirnov). Missing data can be treated using a number of estimation techniques (e.g., Listwise/Pairwise deletion, Mean Imputation, Multiple Imputation) or more elaborate methodologies (for example, see Cordeiro et al, 2010).

For the evaluation of the measurement model, the following properties are assessed: i) reliability, using Cronbach's alpha (suggested minimum value: 0.60) (Narasimhan and Jayaram 1998) and composite reliability of latent variables (suggested minimum value: 0.70) (Nunnally, 1978), ii) discriminant validity, using Fornell and Larcker's (1981) Average Variance Extracted (AVE) of latent variables (suggested minimum value: 0.50; also, AVE for each construct should be greater than the variance shared between the construct and other constructs in the model) and iii) convergent validity, by viewing the loadings of measures to latent variables (a large percentage of the loadings should be above 0.70) (Chin, 1998). In addition, the cross-loadings of the measurement model should be reported in order to show that the measures do not have a stronger connection to other latent variables than those they attempt to reflect. 
For the evaluation of the predictive power of the structural model, Chin (1998) suggests that the standardised paths among latent variables should be at least 0.20 and ideally above 0.30 in order to be considered meaningful. In addition, the following indices are suggested: i) $R^{2}$ for the dependent latent variables included in the model, ii) results of the Stone-Geisser $\mathrm{Q}^{2}$ test for predictive relevance of latent variables and iii) Average Variance Extracted (Chin and Newsted, 1999). However, given the lack of an overall accepted goodness-of-fit index for PLS (Anderson and Gerbing, 1988), the results of the suggested indices should be viewed with caution and under the prism of the overall theoretical predictiveness of the model, represented by the substantial strength and statistical significance of structural paths and their loadings (Chin, 1998). Reporting of PLS results is also suggested to follow this two-stage approach (Chin, 2010).

\subsection{Limitations and further steps for operationalising of the proposed model}

The successful operationalisation and empirical validation of the proposed model requires that the following activities be undertaken:

a) Selection of industrial sectors for which supply chain integration constitutes a legitimate strategic approach.

b) Determination of minimum sample size requirements in relation to the model attributes (e.g., number of observed and unobserved variables) and the modelling approach selected (Partial Least Squares).

c) Selection of respondent characteristics: high-level supply chain / logistics managers, with significant work experience and a global view of supply chain / logistics operations of the firm constitute ideal respondents for this survey.

d) Determination of sample collection outlets: professional organisations willing to involve their members in academic research projects (e.g., CSCMP, ISM, etc.) can be contacted. Moreover, the contact of relevant professional groups from social networking websites (e.g., LinkedIn) can be examined.

e) Collection of a stratified sample across the selected industrial sectors. The representation of as many global regions as possible will increase the global reach of the study.

The major methodological limitation of the proposed model is the use of the 'single key informant' approach as a proxy of the triad 'focal firm - suppliers - customers'. While the use of this approach is theoretically and empirically justified, nevertheless it constitutes a second-best alternative solution to the problem of the incorporation of the opinions of all three supply chain partners in the validation of our model. This characteristic of the modelling approach may also pose a limitation in terms of the need to identify knowledgeable supply chain executives who can provide responses on the relationships of the focal firm with its suppliers and customers; executives with such global knowledge are usually found in high managerial level, which may preclude their participation in this survey.

Another potential limitation may arise due to differences in supply chain relationships on the basis of product type. The characteristics of high-value manufacturing operations (e.g. high-technology products, highly customised products) such as market and demand volatility, technological commitment, and switching costs between suppliers favour the development of relational exchanges between supply chain partners, as opposed to production operations with low level of market/demand volatility and technological complexity (e.g., building materials) which may favour more discrete (i.e., arm's length) 
exchanges and subsequently a less pronounced need for supply chain integration. To this end, it is suggested to focus the survey on industrial sectors that may benefit from higher levels of integration between supply chain partners.

Finally, a potential limitation relates to the degree of participation of the invited respondents due to the length of the survey (102 items). Indeed, the pre-testing of the survey instrument indicated that the average duration of its completion was 20 minutes.

\section{Concluding Remarks}

We have presented a conceptual model for investigating the relationship between behavioural antecedents of collaboration among supply chain partners, supply chain integration and integrated supply chain performance. The proposed model has implications both for academia and for business practice.

With regards to the academic contribution, our model attempts to address several issues considered as limitations in previous related research. Firstly, the model sets out to establish a causal relationship between constructs which have been researched either individually or in combination (for example, the impact of integration on performance, and of collaboration on performance) but not in the holistic manner we propose. Secondly, we set out to represent a causal path which connects these constructs, from behavioural factors which influence the development of collaborative relationships between supply chain partners to the associated impact on performance of the supply chain. We have thus addressed Tokar's (2010, p. 1) challenge laid down in this journal about lack of research on 'developing knowledge concerning human behaviour, judgement and decision making and integrating that knowledge into models, processes and tasks', and we have contributed to van der Vaart and van Donk's (2008) suggestion to investigate the role and impacts of attitudes, patterns and practices on supply chain integration.

More specifically, the relationships between behavioural antecedents of collaboration between supply chain partners and supply chain integration have not received adequate attention, while others (mutuality/reciprocity) have not been researched in a supply chain context. We address these issues in the first part of our conceptual model (hypotheses H1 to H3). The empirical investigation of the link between supply chain integration and performance also requires further elaboration. To date, the relationship between the two has not been adequately established for a number of reasons, including limitation to the perspective of the focal firm, lack of clear delineations of supply chain integration and performance, and difficulty in collecting supply chain-wide performance data. We address these constraints by incorporating in our model dimensions and metrics applicable for assessing supply chain-wide performance (hypotheses $\mathrm{H} 7$ and H8). We therefore aim to provide fresh insights on the impact of behavioural antecedents on supply chain performance through the integration of information and coordination of operational decisions.

The paper also adds to the body of knowledge concerning the use of interorganisational theories in supply chain research and the study of supply chains at the level of interorganisational relationships, which has been identified as a pressing contemporary need in supply chain research (Hammervoll, 2011). The use of Relational Exchange Theory for the selection of the behavioural antecedents of collaboration and the formulation of the respective hypotheses strengthens the use of interorganisational theory, which represents only one percent of the theories used in research on logistics and supply chain management 
(Hammervoll, 2011). Researchers of organisational theories in supply chain management may therefore benefit from the findings of the paper.

In terms of its contribution to business practice, our conceptual model may provide supply chain strategists with insight on how the integration of critical operational contingencies - such as information integration, coordination of operational decisions - can help achieve superior performance across the supply chain. In specific, it may provide guidance to supply chain strategists on the following issues: i) which type(s) of integration - information, operational, both - they should they pursue, ii) how the different dimensions of information and operational integration are interrelated and iii) which dimensions of integration have the highest impact on supply chain performance. The results of the empirical validation of the model should provide more accurate conclusions on the relations between behavioural factors, supply chain integration and performance. In the case that the hypotheses are validated, a roadmap reflecting how the onset of behavioural antecedents in the relationships between supply chain partners can affect integration across the supply chain and consequently lead to higher supply chain performance can be developed. This practical roadmap may stimulate the interest of supply chain strategists towards more collaborative relationship management and affect their decisions on the behavioural factors that guide supply chain relationship formation and management. 


\section{References}

Allen, N.J. and Meyer, J.P. (1990), "The measurement and antecedents of affective, continuance and normative commitment to the organisation", Journal of Occupational Psychology, Vol. 63, pp. 118.

Alwin, D.F. and Krosnick, J.A. (1991), "The reliability of survey attitude measurement: The influence of question and respondent attributes", Sociological Methods \& Research, Vol. 20, No. 1, pp. 139181.

Anderson, J.C. and D.W. Gerbing (1988), "Structural equation modeling in practice: A review and recommended two-stage approach", Psychological Bulletin, Vol. 103, No. 3, pp. 411-423.

Anderson, J.C. and J.A. Narus (1990), "A model of distributor firm and manufacturer firm working partnerships", Journal of Marketing, Vol. 54, pp. 42-58.

Anderson, E. and Weitz, B. (1992), "The use of pledges to build and sustain commitment in distribution channels", Journal of Marketing Research, Vol. 29, No. 1, pp. 18-34.

Bagchi, P. and Skjøett-Larsen, T. (2005), "Supply chain integration: A European survey", International Journal of Logistics Management, Vol. 16, No. 2, pp. 275-294.

Barclay, D.W., Higgins, C. and Thompson, R. (1995), "The partial least squares (PLS) approach to causal modelling: Personal computer adaptation and use as an illustration”, Technology Studies, Vol. 2, No. 2, pp. 285-309.

Barney, J.B. (1991), "Firm resources and sustained competitive advantage", Journal of Management, Vol. 17, No. 1, pp. 99-120.

Bartlett, P.A., Julien, D.M. and Banes, T.S. (2007), "Improving supply chain performance through improved visibility”, International Journal of Logistics Management, Vol. 18, No. 2, pp. 294-313.

Brewer, P.C. and T.W. Speh (2000), "Using the balanced scorecard to measure supply chain performance", Journal of Business Logistics, Vol. 21, No. 1, 2000.

Cai, S. and Z. Yang (2008), "Development of cooperative norms in the buyer-supplier relationship: the Chinese experience", Journal of Supply Chain Management, Vol. 44, No. 1, pp. 55-70.

Campbell, A.J. (1997), "What affects expectations of mutuality in business relationships?", Journal of Marketing Theory and Practice, Vol. 5, No. 4, pp. 1-11.

Caplice, C. and Sheffi, Y. (1994), "A review and evaluation of logistic metrics", International Journal of Logistics Management, Vol. 5, No. 2, pp. 11-28.

Caplice, C. and Sheffi, Y. (1995), "A review and evaluation of logistics performance measurement systems", International Journal of Logistics Management, Vol. 6, No. 1, pp. 61-74.

Chen, H., Daugherty, P.J. and Landry, T.D. (2009), "Supply chain process integration: A theoretical framework", Journal of Business Logistics, Vol. 30, No. 2, pp. 27-46.

Chin, W.W. (1995), "Partial Least Squares is to LISREL as principal components analysis is to common factor analysis", Technology Studies, Vol. 2, pp. 315-319.

Chin, W.W. (1998), "Commentary: Issues and opinions on Structural Equations Modelling", MIS Quarterly, Vol. 22, No. 1, pp. vii-xvi.

Chin, W.W. and Newsted, P.R. (1999), "Structural equation modelling analysis with small samples using partial least squares” in Hoyle, R. (Ed.), Statistical Strategies for Small Sample Research, Sage, London, pp. 307-341. 
Chin, W.W. (2010), "How to write up and report PLS analyses" in Vinzi, V.E., W.W. Chin, J. Henseler and H. Wang (Eds.), Handbook of Partial Least Squares: Concepts, Methods and Applications, Springer, Berlin, pp. 655-690.

Clemmer, E.C., and Schneider. B. (1996), "Fair service" in Brown, S.W., Bowen, D.A. and Swartz, T. (Eds.), Advances in services marketing and management - Volume 5, JAI Press, Greenwich, CT, pp. 109-126.

Closs, D., and Mollenkopf, D. (2004), "A global supply chain framework", Industrial Marketing Management, Vol. 33, No. 1, pp. 37-44.

Cordeiro, C., A. Machás and M.M. Neves (2010), "A case study of a customer satisfaction problem: Bootstrap and implementation techniques" in Vinzi, V.E., W.W. Chin, J. Henseler and H. Wang (Eds.), Handbook of Partial Least Squares: Concepts, Methods and Applications, Springer, Berlin, pp.279-287.

Corsten, D., Gruen, T. and Peyinghaus, I. (2011), "The effects of supplier-to-buyer identification on operational performance - An empirical investigation of inter-organizational identification in automotive relationships", Journal of Operations Management, Vol. 29, pp. 549-560.

Coyle-Shapiro, J. A.-M. and Kessler, I. (2002), "Exploring reciprocity through the lens of the psychological contract: Employee and employer perspectives", European Journal of Work and Organisational Psychology, Vol. 11, No. 1, pp. 69-86.

Croxton, K. (2003), "The order fulfillment process", International Journal of Logistics Management, Vol. 14, No. 1, pp. 19-32.

Cuthbertson, R. and Piotrowicz, W. (2011), "Performance measurement systems in supply chains: A framework for contextual analysis", International Journal of Productivity and Performance Management, Vol. 60, No 6, pp. 583-602.

Dabos, G.E. and Rousseau, D.M. (2004). "Mutuality and reciprocity in the psychological contracts of employers and employees", Journal of Applied Psychology, Vol. 89, No. 1, pp. 52-72.

Danese, P., Romano, P., and Formentini, F. (2013), "The impact of supply chain integration on responsiveness: The moderating effect of using an international supplier network", Transportation Research Part E: Logistics and Transportation Review, Vol. 49, pp. 125-140.

Daugherty, P. J., Myers, M. B. and Richey, R. G. (2002), "Information support for reverse logistics: The influence of relationship commitment", Journal of Business Logistics, Vol. 23, No. 1, pp. 85-106.

Dawes, J. (2008), "Do data characteristics change according to the number of scale points used? An experiment using 5-point, 7-point and 10-point scales", International Journal of Market Research, Vol. 50, No. 1, pp. 61-77.

Dillman, D.A. (2007). Mail and Internet Surveys: The Tailored Design Method, $2^{\text {nd }}$ edition. John Wiley \& Sons, Hoboken, New Jersey.

Doney, P.M. and Cannon, J.P. (1997), "An examination of the nature of trust in buyer-seller relationships", Journal of Marketing, Vol. 61, pp. 35-51.

Droge, C., J. Jayaram and Vickery S. K. (2004), "The effects of internal versus external integration practices on time-based performance and overall firm performance", Journal of Operations Management, Vol. 22, pp. 557-573.

Duffy, R. and Fearne, A. (2004), "The impact of supply chain partnerships on supplier performance", International Journal of Logistics Management, Vol. 15, No. 1, pp. 57-71. 
Dwyer, F.R., Schurr, P.H. and Oh, S. (1987), "Developing buyer-seller relationships", Journal of Marketing, Vol. 51, No. 2, pp. 11-27.

Eng, T.-Y. (2005), "The influence of a firm's cross-functional orientation on supply chain performance", Journal of Supply Chain Management, Vol. 41, No. 4, pp. 4-16.

Emerson, R.M. (1976), "Social exchange theory", Annual Review of Sociology, Vol. 2, pp. 335-362.

Fabbe-Costes, N. and Jahre, M. (2008), "Supply chain integration and performance: a review of the evidence", International Journal of Logistics Management, Vol. 19, No. 2, pp. 130-154.

Fawcett, S.E., Ogden, J.A. and Magnan, G.M. (2006), "Organisational commitment and governance for supply chain success", International Journal of Physical Distribution \& Logistics Management, Vol. 36, No. 1, pp. 22-35.

Flynn, B.B., Huo, B. and Zhao, X. (2010), "The impact of supply chain integration on performance: A contingency and configuration approach", Journal of Operations Management, Vol. 28, No. 1, pp. 58-71.

Fontenot, R.L. and Wilson, E.J. (1997), "Relational exchange: A review of selected models for a prediction matrix of relationship activities", Journal of Business Research, Vol. 39, pp. 5-12.

Fornell, C. and D.F. Larcker (1981), "Evaluating structural equation models with unobservable variables and measurement error", Journal of Marketing Research, Vol. 18, No. 1, pp. 39-50.

Frohlich, M.T. and Westbrook, R. (2001), "Arcs of integration: An international study of supply chain strategies", Journal of Operations Management, Vol. 19, pp. 185-200.

Ganesan S. (1994), "Determinants of long-term orientation in buyer-seller relationships", Journal of Marketing, Vol. 58, No. 2, pp. 1-19.

Gaski, J.F. (1994), "The theory of power and conflict in channels of distribution", Journal of Marketing, Vol. 48, No. 3, pp. 9-29.

Geyskens, I., Steenkamp, J.B.E.M., Scheer, L.K. and Kumar, N. (1996), "The effects of trust and interdependence on relationship commitment: A trans-Atlantic study", International Journal of Research in Marketing, Vol. 13, pp. 303-317.

Green, K.W., Whitten, D. and Innan, R.A. (2008), "The impact of logistics performance on organisational performance in a supply chain context", Supply Chain Management: An International Journal, Vol. 13, No. 4, pp. 317-327.

Gunasekaran, A., Patel, C. and McGaughey, R.E. (2004), "A framework for supply chain performance measurement”, International Journal of Production Economics, Vol. 87, No. 3. pp 333-347.

Gunasekaran, A., Patel, C. and Tirtiroglu, E. (2001), "Performance measures and metrics in a supply chain environment", International Journal of Operations \& Production Management, Vol. 21, No. 1/2, pp. 71-87.

Ha, B.-C., Park, Y.-K. and S. Cho (2011), "Suppliers' affective trust and trust in competency in buyers: Its effect on collaboration and logistics efficiency", International Journal of Operations and Production Management, Vol. 31, No. 1, pp. 56-77.

Hammervoll, T. (2009), "Channel cooperation: a reflective scale", International Journal of Logistics Management, Vol. 20, No. 3, pp. 301-321.

Hammervoll, T. (2011), "Honeymoons in supply chain relationships: the effects of financial capital, social capital and psychological commitment", International Journal of Logistics Management, Vol. 22, No. 2, pp. 264-279. 
Handfield, R., Barnhardt, R. and Powell, N. (2004), "Mapping the automotive textile supply chain: The importance of information visibility" Journal of Textile and Apparel, Technology and Management, Vol. 3, No. 4, pp 1-19.

Handfield, R., and Bechtel, C. (2002), "The role of trust and relationship structure in improving supply chain responsiveness", Industrial Marketing Management, Vol. 31, pp. 367-382.

Heide, J.B. and John, G. (1990), "Alliances in industrial purchasing: The determinants of joint action in buyer-supplier relationships", Journal of Marketing Research, Vol. 27, No. 1, pp. 24-36.

Heide, J.B. and John, G. (1992), "Do norms matter in marketing relationships?", Journal of Marketing, Vol. 56, No. 2, pp. 32-44.

Henseler, J. C.M. Ringle and R.S. Sinkovics (2009), "The use of Partial Least Squares path modelling in international marketing", Advances in International Marketing, Vol. 20, pp. 277-319.

Hernandez-Espallardo, M., Rodriguez-Orejuela, A and Sánchez-Pérez, M. (2010), "Inter-organizational governance, learning and performance in supply chains", Supply Chain Management: An International Journal, Vol. 15, No. 2, pp. 101-114.

Hertz, S. (2001). "Dynamics of alliances in highly integrated supply chain networks", International Journal of Logistics: Research and Applications, Vol, 4, No. 2, pp. 237-256.

Hulland, J., Chow, Y.H. and Lam, S. (1996), "Use of causal models in marketing research: A review", International Journal of Research in Marketing, Vol. 13, pp. 181-197.

Hung. W.-S., Ho, C.-F., Jou, J.-J. and Tai, Y.-M. (2011), "Sharing information strategically in a supply chain: antecedents, content and impact", International Journal of Logistics: Research and Applications, Vol. 14, No. 2, pp. 111-133.

Ivens, B.S. (2005), "Flexibility in industrial service relationships: The construct, antecedents and performance outcomes", Industrial Marketing Management, Vol. 34, pp. 566-576.

Johnston, D.A., McCutcheon, D.M., Stuart, F.I. and Kerwood, H. (2004), "Effects of supplier trust on performance of cooperative supplier relationships", Journal of Operations Management, Vol. 22, pp. 23-38.

Joshi, A.W. and Stump, R.L. (1999), "Determinants of commitment and opportunism: Integrating and extending insights from Transaction Cost Analysis and Relational Exchange Theory", Canadian Journal of Administrative Sciences, Vol. 16, No. 4, pp. 334-352.

Kahn, K.B., Maltz, E.N. and J.T. Mentzer (2006), "Demand collaboration: effects on knowledge creation, relationships and supply chain performance”, Journal of Business Logistics, Vol. 27, No. 2, pp. 191-221.

Kim, S.W. and Narasimhan, R. (2002), "Information system utilization in supply chain integration efforts", International Journal of Production Research, Vol. 40, No. 18, pp. 4585-4609.

Kotzab, H., Teller, C., Grant, D.B. and Sparks, L. (2011), “Antecedents for the adoption and execution of supply chain management”, Supply Chain Management: An International Journal, Vol. 16, No. 4, pp. 231-245.

Koulikoff-Souviron, M. and Harrison, A. (2006), "Buyer-supplier relationships in inter- and intraorganisational supply contexts: the unobtrusive yet pervasive human resource picture", International Journal of Logistics: Research and Applications, Vol. 9, No. 1, pp. 75-94.

Kwon, I.W. and Suh, T. (2005), "Trust, commitment and relationship in supply chain management: a path analysis", Supply Chain Management: An International Journal, Vol. 10, No. 1, pp. 26-33. 
Lado, A.A., Paulraj, A. and Chen. I.J. (2011), "Customer focus, supply-chain relational capabilities and performance: Evidence from US manufacturing industries", Vol. 22, No. 2, pp. 202-221.

Lambe, C.J., Wittmann, C.M. and Spekman, R.E. (2001). "Social Exchange Theory and research on business-to-business relational exchange”, Journal of Business-to-Business Marketing, Vol. 8, No. 3, pp. 1-36.

Lambe, C.J., Spekman, R.E. and Hunt, S.D. (2002), "Alliance competence, resources, and alliance success: Conceptualization, measurement, and initial test", Journal of the Academy of Marketing Science, Vol. 30, No. 2, pp. 141-158.

Lambert, D.M. and Cooper, M.C. (2000), "Issues in supply chain management", Industrial Marketing Management, Vol. 29, pp. 65-83.

Lawrence, P.R. and Lorsch, J.W. (1986), Organisation and environment: Managing differentiation and integration, Harvard Business School Press, Boston, MA.

Lee, H.L. and S. Whang (2000), "Information sharing in a supply chain", International Journal of Manufacturing Technology and Management, Vol. 1, No. 1, pp. 79-93.

McCarthy, T. and Golicic, S.L. (2002), "Implementing collaborative forecasting to improve supply chain performance", International Journal of Physical Distribution and Logistics Management, Vol. 32, No. 6, pp. 431-454.

Menon, G., Bickart, B. Sudman, S. and Blair, J. (1995), How well do you know your partner? Strategies for formulating proxy-reports and their effects on convergence to self-reports", Journal of Marketing Research, Vol. 32, No. 1, pp. 75-84.

Meyer, J.P. and Allen, N.J. (1991), "A three-component conceptualization of organisational commitment", Human Resource Management Review, Vol. 1, No. 1, pp. 61-89.

Min, S., Roath, A.S., Doherty, P.J., Genchev, S.E. Chen, H., Arndt. A.D. and Richey, R.G. (2005) "Supply chain collaboration: what's happening?", International Journal of Logistics Management, Vol. 16, No. 2, pp. 237-256.

Moberg, C.R., T.W. Whipple, B.D. Cutler and T.W. Speh (2004), "Do the management components of supply chain management affect logistics performance?", International Journal of Logistics Management, Vol. 15, No. 2, pp. 15-30.

Mohr, J. J. and Speckman, R. (1994), "Characteristics of partnerships success: partnership attributes, communication behavior, and conflict resolution techniques", Strategic Management Journal, Vol. 15, pp.135-152.

Morgan, R.M., and Hunt, S.D. (1994), "The commitment-trust theory of relationship marketing", Journal of Marketing, Vol. 58, pp. 20-38.

Narasimhan R. and Jayaram, J. (1998), "Causal linkages in supply chain management: An exploratory study of North American manufacturing firms",.Decision Sciences, Vol. 29, No. 3, pp. 579-605.

Neely, A., Mills, J., Platts, K., Gregory, M. and Richards, H. (1996), "Performance measurement system design: Should process based approaches be adopted?", International Journal of Production Economics, Vol. 46-47, pp. 423431.

Noordewier, T.G., John, G. and Nevin, J.R. (1999), "Performance outcomes of purchasing arrangements in industrial buyer-vendor relationships", Journal of Marketing, Vol. 54, No. 4, pp. 80-93.

Nyaga, G.N., Whipple, J.M. and Lynch, D.F. (2010), "Examining supply chain relationships: Do buyer and supplier perspectives on collaborative relationships differ?", Journal of Operations Management, Vol. 28, pp. 101-114. 
Nyaga, G.N. and Whipple, J.M. (2011), "Relationship quality and performance outcomes: achieving a sustainable competitive advantage", Journal of Business Logistics, Vol. 32, No. 4, pp. 345-360.

Nunnally, J.C. (1978), Psychometric Theory, McGraw-Hill, New York, NY.

Oliver C. (1990), "Determinants of interorganisational relationships: Integration and future directions", The Academy of Management Review, Vol. 15, No. 2, pp. 241-265.

Panayides, P.M. and Lun, V (2009), "The impact of trust on innovativeness and supply chain performance", International Journal of Production Economics, Vol. 122, pp. 35-46.

Paulraj, A, Lado, A.A. and Chen, I.J. (2008), "Inter-organizational communication as a relational competency: Antecedents and performance outcomes in collaborative buyer-supplier relationships", Journal of Operations Management, Vol. 26, pp. 45-64.

Petersen, K.J., Ragatz. G.L. and Monczka, R.M. (2005), "An examination of collaborative planning effectiveness and supply chain performance", Journal of Supply Chain Management, Vol. 41, No. 2, pp. 14-25.

Prajogo, D. and J. Olhager (2012), "Supply chain integration and performance: The effects of long-term relationships, information technology and sharing, and logistics integration", International Journal of Production Economics, Vol. 135, pp 514-522.

Premkumar, G., Ramamurthy, K. and Saunders, C.S. (2005), "Information processing view of organizations: An exploratory examination of fit in the context of interorganisational relationships", Journal of Management Information Systems, Vol. 22, No. 1, pp. 257-294.

Quinn, R.W. and J.E. Dutton (2005). Coordination as energy-in-conversation. Academy of Management Review, Vol. 30, No. 1, pp. 36-57.

Ring, P.S. and van de Ven, A.H. (1992), "Structuring cooperative relationships between organisations. Strategic Management Journal, Vol. 13, pp. 483-498.

Ryu, Il, S. So and C. Koo (2009), "The role of partnership in supply chain governance", Industrial Management \& Data Systems, Vol. 109, No. 4, pp. 496-514.

Sanders, N.R., Autry, C.W. and Gligor, D.M. (2011), "The impact of buyer firm information connectivity enablers on supplier firm performance: a relational view”, International Journal of Logistics Management, Vol. 22, No. 2, pp. 179-201.

Seppanen, R., Blomqvist, K. and Sundqvist, S. (2007), "Measuring inter-organisational trust - a critical review of the empirical research in 1990-2003”, Industrial Marketing Management, Vol. 36, pp. 249-265.

Shepherd, C. and Günther, H., (2006), "Measuring supply chain performance: current research and future directions", International Journal of Productivity and Performance Management, Vol. 55, No. 3/4, pp. 242-258.

Shub, A.N. and Stonebraker, P.W. (2009), "The human impact on supply chains: evaluating the importance of "soft" areas on integration and performance", Supply Chain Management: An International Journal, Vol. 14, No. 1, pp. 31-40.

Simatupang, T.M. and Sridharan, R. (2002), “The collaborative supply chain”, International Journal of Supply Chain Management, Vol. 13, No. 1, pp. 15-30.

Subramani, M. and Venkatraman, N. (2003), "Safeguarding investments in asymmetric interorganisational relationships: Theory and evidence", The Academy of Management Journal, Vol. 46, No. 1, pp. 46-62.

Thompson, J.D. (1967). Organizations in Action, McGraw-Hill, New York. 
Tokar, T. (2010), "Behavioural research in logistics and supply chain management", International Journal of Logistics Management, Vol. 21, No. 1, pp. 89-103.

van der Vaart, T. and D.P. van Donk (2008), “A critical review of survey-based research in supply chain integration", International Journal of Production Economics, Vol. 111, pp. 42-55.

van der Vaart, T., van Donk, D.P., Gimenez, C. and V. Sierra (2012), "Modelling the integrationperformance relationship: Collaborative practices, enablers and contextual factors", International Journal of Productions and Operations Management, Vol. 32, No. 9, 2012.

van Tilburg, T., van Sonderen, E. and Ormel, J. (1991), "The measurement of reciprocity in ego-centered networks of personal relationships: a comparison of various indices", Social Psychology Quarterly, Vol. 54, No. 1, pp. 54-66.

Vollman, T.E., W.L. Berry, D. C. Whybark and F.R. Jacobs (2005). Manufacturing Planning and Control Systems for Supply Chain Management, $5^{\text {th }}$ edition, McGraw Hill, New York.

Whipple, J.M. and Russell, D. (2007), "Building supply chain collaboration: a typology of collaborative approaches", International Journal of Logistics Management, Vol. 18, No. 2, pp. 174-196.

Williamson, O.E. (1985), The economic institutions of capitalism, Free Press, New York, NY.

Wu, W.-Y., Chiag, C.-Y., Wu, Y.-J. and Tu, H.-J. (2004), "The influencing factors of commitment and business integration on supply chain management", Industrial Management \& Data Systems, Vol. 104, No. 4, pp. 322-333.

Xiao, Y., Zheng, X., Pan, W. and Xie, X. (2010), "Trust, relationship commitment and cooperative performance: supply chain management”, Chinese Management Studies, Vol. 4, No. 3, pp. 231 243.

Zacharia, Z.G., Nix, N.W. and Lusch, R.F. (2009), “An analysis of supply chain collaborations and their performance outcomes", Journal of Business Logistics, Vol. 30, No. 2, pp. 101-123.

Zhao, X., Huo, B., Flynn, B.B. and Yeung, J.H.Y. (2008), "The impact of power and relationship commitment on the integration between manufacturers and customers in a supply chain", Journal of Operations Management, Vol. 26, pp. 368-388. 
Figure 1: Conceptual Model for Examining the Supply Chain Relationships between Behavioural Antecedents of Collaboration, Integration and

\section{Performance}

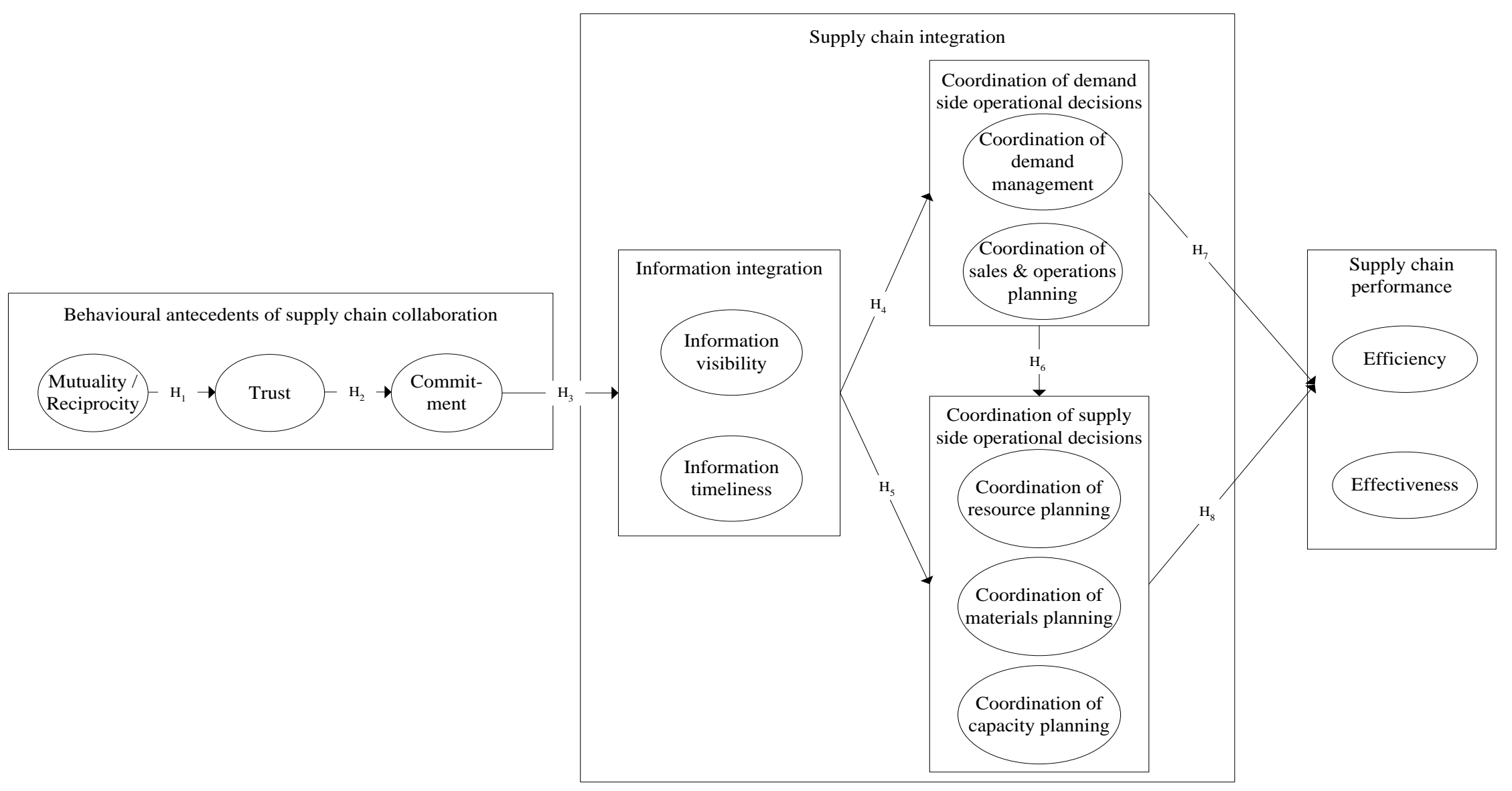


Table 1. Results of literature review on relationship between behavioural factors, supply chain integration and supply chain performance

\begin{tabular}{|c|c|c|c|c|c|c|}
\hline Reference & $\begin{array}{l}\text { Theoretical context } \\
\text { / background }\end{array}$ & Behavioural factors & $\begin{array}{l}\text { Cooperation/integration } \\
\text { dimensions }\end{array}$ & $\begin{array}{l}\text { Performance dimensions / } \\
\text { metrics }\end{array}$ & Results (hypotheses supported) & Comments \\
\hline $\begin{array}{l}\text { Cai and Yang } \\
(2008)\end{array}$ & $\begin{array}{l}\text { Transaction cost } \\
\text { economics, } \\
\text { resource } \\
\text { dependence theory }\end{array}$ & $\begin{array}{l}\text { Cooperative norms: } \\
\text { belief and } \\
\text { expectation that two } \\
\text { parties must work } \\
\text { together to achieve } \\
\text { mutual goals }\end{array}$ & $\begin{array}{l}\text { The model does not } \\
\text { examine supply chain } \\
\text { integration }\end{array}$ & $\begin{array}{l}\text { Supplier performance: } \\
\text { product quality, on-time } \\
\text { delivery, meeting target } \\
\text { costs, } \\
\text { sales/service/technical } \\
\text { support }\end{array}$ & $\begin{array}{l}\text { Supply importance, availability of } \\
\text { alternative, env. uncertainty, } \\
\text { magnitude of TSI, frequency of } \\
\text { transaction, legal contracts } \rightarrow \\
\text { cooperative norms } \\
\text { Length of relationship } \rightarrow \text { supplier } \\
\text { performance } \\
\text { Cooperative norms } \rightarrow \text { supplier } \\
\text { performance }\end{array}$ & $\begin{array}{l}\text { The model also examines } \\
\text { antecedents of } \\
\text { cooperative norms } \\
\text { (dependence, exchange } \\
\text { hazards, norm facilitators) }\end{array}$ \\
\hline $\begin{array}{l}\text { Corsten et al } \\
(2011)\end{array}$ & & 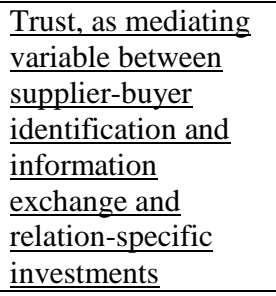 & Information exchange & $\begin{array}{l}\text { Innovation } \\
\text { Cost performance } \\
\text { Disturbances (volatility, } \\
\text { failure) }\end{array}$ & $\begin{array}{l}\text { Trust mediates the effect of supplier- } \\
\text { buyer identification on information } \\
\text { exchange } \\
\text { Information exchange positively } \\
\text { affects innovation and disturbances } \\
\underline{\text { but not cost }}\end{array}$ & $\begin{array}{l}\text { Model was tested in } \\
\text { automotive industry only. }\end{array}$ \\
\hline $\begin{array}{l}\text { Duffy and } \\
\text { Fearne (2004) }\end{array}$ & $\begin{array}{l}\text { Buyer-seller } \\
\text { relationships }\end{array}$ & $\begin{array}{l}\text { Climate: } \\
\text { Trust and relational } \\
\text { norms } \\
\text { Commitment } \\
\text { Functional conflict } \\
\text { resolution methods }\end{array}$ & $\begin{array}{l}\text { The model does not } \\
\text { examine supply chain } \\
\text { integration }\end{array}$ & $\begin{array}{l}\text { Future growth } \\
\text { Current costs and sales }\end{array}$ & $\begin{array}{l}\text { Climate is positively related to } \\
\text { performance. Commitment is the best } \\
\text { predictor of performance, followed } \\
\text { by trust and relational norms, and } \\
\text { functional conflict resolution }\end{array}$ & $\begin{array}{l}\text { Examined relationship is } \\
\text { one out of three (the other } \\
\text { two are: economy } \rightarrow \\
\text { performance and polity } \rightarrow \\
\text { performance). Model was } \\
\text { tested in UK food } \\
\text { industry only. }\end{array}$ \\
\hline Eng (2005) & $\begin{array}{l}\text { Resource } \\
\text { dependence theory, } \\
\text { relational norms }\end{array}$ & $\begin{array}{l}\frac{\text { Part of }}{\text { "Interfunctional }} \\
\text { cooperation" } \\
\text { Joint attempt to } \\
\text { achieve individual } \\
\text { and mutual goals } \\
\text { Part of "Information } \\
\text { exchange" } \\
\text { Trust } \\
\text { Communication }\end{array}$ & $\begin{array}{l}\text { Cross-functional } \\
\text { orientation (CFO) }\end{array}$ & $\begin{array}{l}\text { Customer satisfaction } \\
\text { Supply chain } \\
\text { responsiveness }\end{array}$ & $\begin{array}{l}\text { Interfunctional cooperation } \rightarrow \mathrm{CFO} \\
\text { Information exchange } \rightarrow \text { CFO } \\
\mathrm{CFO} \rightarrow \text { Customer satisfaction } \\
\mathrm{CFO} \rightarrow \text { Supply chain responsiveness }\end{array}$ & \\
\hline $\begin{array}{l}\text { Green et al } \\
(2008)\end{array}$ & $\begin{array}{l}\text { Review of supply } \\
\text { chain literature }\end{array}$ & $\begin{array}{l}\text { Trust (as part of } \\
\text { construct "SCM } \\
\text { strategy") }\end{array}$ & $\begin{array}{l}\text { The model does not } \\
\text { examine supply chain } \\
\text { integration }\end{array}$ & $\begin{array}{l}\text { Logistics performance } \\
\text { Marketing performance } \\
\text { Financial performance } \\
\end{array}$ & $\begin{array}{l}\text { SCM strategy } \rightarrow \text { logistics perf. } \\
\text { SCM strategy } \rightarrow \text { marketing perf. }\end{array}$ & \\
\hline
\end{tabular}




\begin{tabular}{|c|c|c|c|c|c|c|}
\hline Reference & $\begin{array}{l}\text { Theoretical context } \\
\text { / background }\end{array}$ & Behavioural factors & $\begin{array}{l}\text { Cooperation/integration } \\
\text { dimensions }\end{array}$ & $\begin{array}{l}\text { Performance dimensions / } \\
\text { metrics }\end{array}$ & Results (hypotheses supported) & Comments \\
\hline Ha et al (2011) & & $\begin{array}{l}\text { Trust between buyer } \\
\text { and supplier: } \\
\text { affective trust, trust } \\
\text { in competency }\end{array}$ & $\begin{array}{l}\text { Collaboration } \\
\text { Joint decision-making } \\
\text { Information sharing } \\
\text { Benefit/risk sharing }\end{array}$ & $\begin{array}{l}\text { Logistics efficiency of } \\
\text { supplier firm: } \\
\text { Order fill rate } \\
\text { Order fulfilment lead time } \\
\text { Operations flexibility } \\
\text { Inventory turnover } \\
\text { Total logistics cost }\end{array}$ & $\begin{array}{l}\text { Affective trust } \rightarrow \text { Information } \\
\text { sharing } \\
\text { Affective trust } \rightarrow \text { Benefit/risk } \\
\text { sharing } \\
\text { Trust in competency } \rightarrow \text { Joint } \\
\text { decision-making } \\
\text { Trust in competency } \rightarrow \text { Benefit/risk } \\
\text { sharing } \\
\text { Joint decision-making } \rightarrow \text { Logistics } \\
\text { efficiency } \\
\text { Information sharing } \rightarrow \text { Logistics } \\
\text { efficiency }\end{array}$ & \\
\hline $\begin{array}{l}\text { Handfield and } \\
\text { Bechtel (2004) }\end{array}$ & $\begin{array}{l}\text { Buyer-seller } \\
\text { relationships }\end{array}$ & $\begin{array}{l}\text { Supplier trust to } \\
\text { buyers }\end{array}$ & $\begin{array}{l}\text { The model does not } \\
\text { examine supply chain } \\
\text { integration }\end{array}$ & $\begin{array}{l}\text { Supply chain } \\
\text { responsiveness }\end{array}$ & Trust $\rightarrow$ responsiveness & Part of larger model \\
\hline $\begin{array}{l}\text { Hernandez- } \\
\text { Espallardo et al } \\
(2010)\end{array}$ & $\begin{array}{l}\text { Interorganisational } \\
\text { learning, } \\
\text { transaction cost } \\
\text { economics, } \\
\text { relational } \\
\text { marketing }\end{array}$ & $\begin{array}{l}\text { Social enforcement: } \\
\text { Promises } \\
\text { Honesty } \\
\text { Mutual cooperation } \\
\text { in differences }\end{array}$ & $\begin{array}{l}\text { The model does not } \\
\text { examine supply chain } \\
\text { integration }\end{array}$ & Firm performance & $\begin{array}{l}\text { Social enforcement } \rightarrow \text { firm } \\
\text { performance }\end{array}$ & \\
\hline $\begin{array}{l}\text { Hung et al } \\
\text { (2011) }\end{array}$ & $\begin{array}{l}\text { Information sharing } \\
\text { strategy }\end{array}$ & $\begin{array}{l}\text { Trust } \\
\text { Commitment }\end{array}$ & $\begin{array}{l}\text { Information sharing } \\
\text { (quality, breadth, } \\
\text { formalisation, mutual } \\
\text { adjustment) }\end{array}$ & $\begin{array}{l}\text { Cost per unit } \\
\text { Productivity standards } \\
\text { On-time delivery } \\
\text { Respond to requests } \\
\text { Inventory requirements }\end{array}$ & $\begin{array}{l}\text { Trust } \rightarrow \text { quality of info sharing, } \\
\text { breadth of info sharing, } \\
\text { formalisation, mutual adjustment } \\
\text { Commitment } \rightarrow \text { quality of info } \\
\text { sharing, breadth of info sharing, } \\
\text { formalisation, mutual adjustment } \\
\text { Quality, breadth, formalisation, } \\
\text { mutual adjustment } \rightarrow \text { performance } \\
\text { (via supply chain uncertainty) }\end{array}$ & \\
\hline $\begin{array}{l}\text { Johnston et al } \\
\text { (2004) }\end{array}$ & $\begin{array}{l}\text { Buyer-seller } \\
\text { relationships }+ \\
\text { other types of inter- } \\
\text { firm relationships }\end{array}$ & $\begin{array}{l}\text { Supplier trust } \\
\text { (benevolence, } \\
\text { dependability) }\end{array}$ & $\begin{array}{l}\text { Cooperative relationship } \\
\text { behaviour: } \\
\text { Joint responsibility } \\
\text { Shared planning } \\
\text { Flexibility in } \\
\text { arrangements }\end{array}$ & $\begin{array}{l}\text { Relationship performance } \\
\text { (buyer's view): long-term } \\
\text { profitability, net profits } \\
\text { over past year, growth, } \\
\text { innovation of } \\
\text { products/services, lower } \\
\text { long-term costs, lower } \\
\text { short-term costs, } \\
\text { increased quality, } \\
\text { increased product/service } \\
\text { base }\end{array}$ & $\begin{array}{l}\text { Trust } \rightarrow \text { joint responsibility } \\
\text { Trust } \rightarrow \text { shared planning } \\
\text { Trust } \rightarrow \text { flexibility } \\
\text { Flexibility } \rightarrow \text { performance } \\
\text { Shared planning } \rightarrow \text { performance }\end{array}$ & $\begin{array}{l}\text { No assessment of impact } \\
\text { on specific performance } \\
\text { measures }\end{array}$ \\
\hline
\end{tabular}




\begin{tabular}{|c|c|c|c|c|c|c|}
\hline Reference & $\begin{array}{l}\text { Theoretical context } \\
\text { / background }\end{array}$ & Behavioural factors & $\begin{array}{l}\text { Cooperation/integration } \\
\text { dimensions }\end{array}$ & $\begin{array}{l}\text { Performance dimensions / } \\
\text { metrics }\end{array}$ & Results (hypotheses supported) & Comments \\
\hline $\begin{array}{l}\text { Kahn et al } \\
(2006)\end{array}$ & $\begin{array}{l}\text { Relational and } \\
\text { technology aspects } \\
\text { of collaboration }\end{array}$ & $\begin{array}{l}\text { Some behavioural } \\
\text { factors constitute } \\
\text { characteristics of the } \\
\text { types of } \\
\text { collaboration } \\
\text { examined }\end{array}$ & $\begin{array}{l}\text { Four types of } \\
\text { collaboration } \\
\text { Transaction-based } \\
\text { Technology-based } \\
\text { Affinity-based } \\
\text { Integral-based }\end{array}$ & $\begin{array}{l}\text { Reduction of inventory } \\
\text { levels } \\
\text { Order level precision }\end{array}$ & $\begin{array}{l}\text { Transaction-based demand } \\
\text { collaboration reflects lower level of } \\
\text { SC performance in terms of creating } \\
\text { value-laden relationships (esprit de } \\
\text { corps, information effectiveness, and } \\
\text { trust) than affinity-based } \\
\text { collaboration }\end{array}$ & $\begin{array}{l}\text { Affinity-based } \\
\text { collaboration depends the } \\
\text { most on trust and } \\
\text { commitment among } \\
\text { partners }\end{array}$ \\
\hline $\begin{array}{l}\text { Kim and } \\
\text { Narasimhan } \\
(2002)\end{array}$ & $\begin{array}{l}\text { Resource-based } \\
\text { view and } \\
\text { transaction cost } \\
\text { theory }\end{array}$ & $\begin{array}{l}\text { The model does not } \\
\text { examine behavioural } \\
\text { factors }\end{array}$ & $\begin{array}{l}\text { Integration with suppliers: } \\
\text { info exchange, strategic } \\
\text { partnership, participation } \\
\text { in design stage, } \\
\text { participation in } \\
\text { procurement / production, } \\
\text { quick ordering, stable } \\
\text { procurement } \\
\text { Integration with } \\
\text { customers: follow-up for } \\
\text { feedback, computerization } \\
\text { of customer ordering, } \\
\text { information network, } \\
\text { market info sharing, } \\
\text { agility of ordering, } \\
\text { contact frequency, } \\
\text { communication }\end{array}$ & $\begin{array}{l}\text { Sales growth and market } \\
\text { share growth } \\
\text { Profitability } \\
\text { ROI, ROA, revenue } \\
\text { growth, financial } \\
\text { liquidity, net profit }\end{array}$ & $\begin{array}{l}\text { Product diversification in SCs with } \\
\text { high level of integration with } \\
\text { suppliers and customers can increase } \\
\text { performance (as defined here) }\end{array}$ & $\begin{array}{l}\text { Integration with suppliers } \\
\text { and customers as } \\
\text { moderating variable } \\
\text { between international } \\
\text { market diversification and } \\
\text { firm performance }\end{array}$ \\
\hline $\begin{array}{l}\text { Kotzab et al } \\
(2011)\end{array}$ & $\begin{array}{l}\text { Review of supply } \\
\text { chain literature }\end{array}$ & $\begin{array}{l}\text { Part of "Joint SCM } \\
\text { conditions": } \\
\text { Trust } \\
\text { Commitment } \\
\text { Distribution of risks } \\
\text { and benefits } \\
\text { Mutual dependency }\end{array}$ & $\begin{array}{l}\text { As "Execution of SCM } \\
\text { processes": } \\
\text { Internal integration } \\
\text { Integration with suppliers } \\
\text { Integration with } \\
\text { customers }\end{array}$ & $\begin{array}{l}\text { The model does not } \\
\text { examine supply chain } \\
\text { performance }\end{array}$ & $\begin{array}{l}\text { Joint SCM conditions } \rightarrow \text { adoption of } \\
\text { SCM-related processes } \\
\text { Adoption of SCM-related processes } \\
\rightarrow \text { Execution of SCM processes }\end{array}$ & \\
\hline $\begin{array}{l}\text { Lado et al } \\
\text { (2011) }\end{array}$ & $\begin{array}{l}\text { Review of supply } \\
\text { chain literature, } \\
\text { strategic } \\
\text { management, } \\
\text { marketing }\end{array}$ & $\begin{array}{l}\text { SC relational } \\
\text { capabilities: long- } \\
\text { term relationship, } \\
\text { interorganisational } \\
\text { communication, } \\
\text { cross-functional } \\
\text { teams, supplier } \\
\text { involvement }\end{array}$ & $\begin{array}{l}\text { The model does not } \\
\text { examine supply chain } \\
\text { integration }\end{array}$ & $\begin{array}{l}\text { Firm's financial } \\
\text { performance: ROI, profit } \\
\text { as \% of sales, net income } \\
\text { before tax }\end{array}$ & $\begin{array}{l}\text { Customer focus } \rightarrow \text { SC relational } \\
\text { capabilities } \\
\text { Customer focus } \rightarrow \text { Customer service } \\
\text { SC relational capabilities } \rightarrow \\
\text { Customer service } \\
\text { Customer service } \rightarrow \text { Financial } \\
\text { performance }\end{array}$ & \\
\hline Moberg (2004) & $\begin{array}{l}\text { Review of relevant } \\
\text { SCM literature }\end{array}$ & $\begin{array}{l}\text { SCM commitment } \\
\text { Trust } \\
\text { Relationship } \\
\text { commitment }\end{array}$ & $\begin{array}{l}\text { The model does not } \\
\text { examine supply chain } \\
\text { integration }\end{array}$ & $\begin{array}{l}\text { Logistics costs } \\
\text { Logistics service }\end{array}$ & $\begin{array}{l}\text { SCM commitment } \rightarrow \text { performance } \\
\text { Trust } \rightarrow \text { performance } \\
\text { Relationship commitment } \rightarrow \\
\text { performance }\end{array}$ & $\begin{array}{l}\text { Logistics cost and service } \\
\text { measures only - no } \\
\text { supply chain or firm } \\
\text { measures }\end{array}$ \\
\hline
\end{tabular}




\begin{tabular}{|c|c|c|c|c|c|c|}
\hline Reference & $\begin{array}{l}\text { Theoretical context } \\
\text { / background }\end{array}$ & Behavioural factors & $\begin{array}{l}\text { Cooperation/integration } \\
\text { dimensions }\end{array}$ & $\begin{array}{l}\text { Performance dimensions / } \\
\text { metrics }\end{array}$ & Results (hypotheses supported) & Comments \\
\hline $\begin{array}{l}\text { Nyaga et al, } \\
(2010)\end{array}$ & $\begin{array}{l}\text { Transaction Cost } \\
\text { Analysis, social } \\
\text { exchange theory }\end{array}$ & $\begin{array}{l}\text { Trust } \\
\text { Commitment }\end{array}$ & $\begin{array}{l}\text { Collaborative activities: } \\
\text { Information sharing } \\
\text { Joint relationship effort } \\
\text { Dedicated investments }\end{array}$ & $\begin{array}{l}\text { Order cycle time } \\
\text { Order processing } \\
\text { accuracy } \\
\text { On-time delivery } \\
\text { Forecast accuracy }\end{array}$ & $\begin{array}{l}\text { Information sharing } \rightarrow \text { commitment } \\
\text { (buyer and supplier models) } \\
\text { Information sharing } \rightarrow \text { trust (buyer } \\
\text { and supplier models) } \\
\text { Joint relationship effort } \rightarrow \text { trust } \\
\text { (buyer and supplier models) } \\
\text { Trust } \rightarrow \text { Commitment (buyer and } \\
\text { supplier models) } \\
\text { Trust } \rightarrow \text { Performance (buyer and } \\
\text { supplier models) } \\
\text { Commitment } \rightarrow \text { Performance (buyer } \\
\text { model) }\end{array}$ & $\begin{array}{l}\text { The model hypothesises } \\
\text { that collaborative } \\
\text { activities affect } \\
\text { performance through the } \\
\text { mediation of trust and } \\
\text { commitment. Two models } \\
\text { tested (collaboration of } \\
\text { firm with buyers, with } \\
\text { suppliers) }\end{array}$ \\
\hline $\begin{array}{l}\text { Nyaga and } \\
\text { Whipple (2011) }\end{array}$ & $\begin{array}{l}\text { Resource-based } \\
\text { view, relational } \\
\text { view }\end{array}$ & $\begin{array}{l}\text { Relationship quality } \\
\text { Trust } \\
\text { Commitment } \\
\text { Satisfaction } \\
\text { Relationship-specific } \\
\text { investment }\end{array}$ & $\begin{array}{l}\text { The model does not } \\
\text { examine supply chain } \\
\text { integration }\end{array}$ & $\begin{array}{l}\text { Operational performance: } \\
\text { order cycle time, order } \\
\text { processing accuracy, on- } \\
\text { time delivery, forecast } \\
\text { accuracy } \\
\text { Satisfaction with strategic } \\
\text { performance: } \\
\text { profitability, market } \\
\text { share, sales growth }\end{array}$ & $\begin{array}{l}\text { Relationship quality } \rightarrow \text { operational } \\
\text { performance } \\
\text { Relationship quality } \rightarrow \text { satisfaction } \\
\text { with strategic performance }\end{array}$ & \\
\hline $\begin{array}{l}\text { Panayides and } \\
\text { Lun (2009) }\end{array}$ & $\begin{array}{l}\text { Relational } \\
\text { exchange }\end{array}$ & Trust & $\begin{array}{l}\text { The model does not } \\
\text { examine supply chain } \\
\text { integration }\end{array}$ & $\begin{array}{l}\text { Cost reduction } \\
\text { Delivery reliability } \\
\text { Quality improvement } \\
\text { Conformance to } \\
\text { specifications } \\
\text { Lead times } \\
\text { Time to market } \\
\text { Process improvement }\end{array}$ & Trust $\rightarrow$ supply chain performance & $\begin{array}{l}\text { The model also } \\
\text { investigates the impact of } \\
\text { trust on innovativeness } \\
\text { and of innovativeness on } \\
\text { SC performance. Both } \\
\text { hypotheses are supported. }\end{array}$ \\
\hline $\begin{array}{l}\text { Paulraj et al } \\
\text { (2008) }\end{array}$ & Relational view & $\begin{array}{l}\text { Long-term } \\
\text { relationship } \\
\text { orientation } \\
\text { Network governance: } \\
\text { informal social } \\
\text { systems including } \\
\text { norms such as } \\
\text { solidarity, mutuality, } \\
\text { flexibility }\end{array}$ & $\begin{array}{l}\text { Inter-organisational } \\
\text { communication: } \\
\text { information sharing }\end{array}$ & $\begin{array}{l}\text { Buyer performance } \\
\text { (various operational } \\
\text { measures) } \\
\text { Supplier performance } \\
\underline{\text { (various operational }} \\
\underline{\text { measures) }}\end{array}$ & $\begin{array}{l}\text { Long-term relationship orientation } \rightarrow \\
\text { inter-organisational communication } \\
\text { Network governance } \rightarrow \text { inter- } \\
\text { organisational communication } \\
\text { Inter-organisational communication } \\
\rightarrow \text { buyer and supplier performance }\end{array}$ & $\begin{array}{l}\text { Model also examines the } \\
\text { impact of information } \\
\text { technology use on inter- } \\
\text { organisational } \\
\text { communication }\end{array}$ \\
\hline
\end{tabular}




\begin{tabular}{|c|c|c|c|c|c|c|}
\hline Reference & $\begin{array}{l}\text { Theoretical context } \\
\text { / background }\end{array}$ & Behavioural factors & $\begin{array}{l}\text { Cooperation/integration } \\
\text { dimensions }\end{array}$ & $\begin{array}{l}\text { Performance dimensions / } \\
\text { metrics }\end{array}$ & Results (hypotheses supported) & Comments \\
\hline $\begin{array}{l}\text { Petersen et al } \\
(2005)\end{array}$ & $\begin{array}{l}\text { Resource based } \\
\text { view, relational } \\
\text { view }\end{array}$ & $\begin{array}{l}\text { Trust } \\
\text { Information quality }\end{array}$ & $\begin{array}{l}\text { Collaborative planning } \\
\text { Supplier scheduling } \\
\text { Forecasting and inventory } \\
\text { positioning } \\
\text { Inventory visibility } \\
\text { Capacity planning } \\
\text { Post-selection supplier } \\
\text { evaluation } \\
\text { Proposal evaluation } \\
\text { Joint goal/target setting } \\
\text { Part/material } \\
\text { standardization }\end{array}$ & $\begin{array}{l}\text { Supply chain performance } \\
\text { Material cost performance } \\
\text { Inventory turns } \\
\text { Supplier performance }\end{array}$ & $\begin{array}{l}\text { Trust } \rightarrow \text { Collaborative planning } \\
\text { Information quality } \rightarrow \text { Collaborative } \\
\text { planning } \\
\text { Collaborative planning } \rightarrow \text { Supply } \\
\text { chain performance }\end{array}$ & \\
\hline $\begin{array}{l}\text { Prajogo and } \\
\text { Olhager (2012) }\end{array}$ & $\begin{array}{l}\text { Review of supply } \\
\text { chain literature }\end{array}$ & $\begin{array}{l}\text { Long-term } \\
\text { relationships: }\end{array}$ & $\begin{array}{l}\text { Information sharing } \\
\text { Logistics integration }\end{array}$ & $\begin{array}{l}\text { Firm performance } \\
\text { Final product } \\
\text { performance } \\
\text { Speed of deliveries } \\
\text { Volume/capacity } \\
\text { flexibility } \\
\text { Product variety } \\
\text { Production costs }\end{array}$ & $\begin{array}{l}\text { Long term relationship } \rightarrow \\
\text { Information sharing } \\
\text { Information sharing } \rightarrow \text { Logistics } \\
\text { integration } \\
\text { Logistics integration } \rightarrow \text { Firm } \\
\text { performance } \\
\text { Long term relationship } \rightarrow \text { Firm } \\
\text { performance }\end{array}$ & $\begin{array}{l}\text { Model also examines the } \\
\text { impact of long term } \\
\text { relationships on IT use } \\
\text { and the impact of IT use } \\
\text { on logistics integration. } \\
\text { Both hypotheses are } \\
\text { supported. }\end{array}$ \\
\hline Ryu et al (2009) & $\begin{array}{l}\text { Long-term buyer- } \\
\text { seller relationships }\end{array}$ & $\begin{array}{l}\text { Trust } \\
\text { Commitment } \\
\text { Collaboration }\end{array}$ & $\begin{array}{l}\text { The model does not } \\
\text { examine supply chain } \\
\text { integration }\end{array}$ & $\begin{array}{l}\text { Product delivery cycle } \\
\text { time } \\
\text { Productivity } \\
\text { Decrease of costs } \\
\text { Increase of revenues } \\
\end{array}$ & $\begin{array}{l}\text { Trust } \rightarrow \text { commitment } \\
\text { Trust } \rightarrow \text { collaboration } \\
\text { Commitment } \rightarrow \text { collaboration } \\
\text { Collaboration } \rightarrow \text { performance }\end{array}$ & \\
\hline $\begin{array}{l}\text { Sanders et al } \\
\text { (2011) }\end{array}$ & Relational view & $\begin{array}{l}\text { The model does not } \\
\text { examine behavioural } \\
\text { factors }\end{array}$ & $\begin{array}{l}\text { Not explicitly identified } \\
\text { as integration dimensions } \\
\text { Buyer-to-supplier: } \\
\text { information sharing, } \\
\text { performance feedback, } \\
\text { communication openness } \\
\text { Buyer: investment in IT }\end{array}$ & $\begin{array}{l}\text { Supplier performance } \\
\text { (cost improvement, } \\
\text { product quality } \\
\text { improvement, new } \\
\text { product introduction time, } \\
\text { delivery speed } \\
\text { improvement) }\end{array}$ & $\begin{array}{l}\text { Information sharing } \rightarrow \\
\text { communication openness } \\
\text { Performance feedback } \rightarrow \\
\text { communication openness } \\
\text { Investment in IT } \rightarrow \text { communication } \\
\text { openness } \\
\text { Communication openness } \rightarrow \text { supplier } \\
\text { performance }\end{array}$ & \\
\hline $\begin{array}{l}\text { Shub and } \\
\text { Stonebraker } \\
\text { (2009) }\end{array}$ & $\begin{array}{l}\text { Transaction-based } \\
\text { and human } \\
\text { resource-based } \\
\text { strategies }\end{array}$ & $\begin{array}{l}\text { HR strategies: } \\
\text { staffing, training, } \\
\text { evaluation, } \\
\text { compensation } \\
\text { Organisational } \\
\text { strategies: structure, } \\
\text { culture, commitment }\end{array}$ & $\begin{array}{l}\text { Supply chain integration } \\
\text { (no additional delineation) }\end{array}$ & $\begin{array}{l}\text { Supply chain performance } \\
\text { (no additional } \\
\text { delineation) }\end{array}$ & & $\begin{array}{l}\text { Only conceptual model - } \\
\text { no empirical validation }\end{array}$ \\
\hline
\end{tabular}




\begin{tabular}{|c|c|c|c|c|c|c|}
\hline Reference & $\begin{array}{l}\text { Theoretical context } \\
\text { / background }\end{array}$ & Behavioural factors & $\begin{array}{l}\text { Cooperation/integration } \\
\text { dimensions }\end{array}$ & $\begin{array}{l}\text { Performance dimensions / } \\
\text { metrics }\end{array}$ & Results (hypotheses supported) & Comments \\
\hline $\begin{array}{l}\text { van der Vaart et } \\
\text { al (2012) }\end{array}$ & $\begin{array}{l}\text { Supply chain } \\
\text { theory }\end{array}$ & $\begin{array}{l}\text { Cooperative } \\
\text { behaviour: shared } \\
\text { responsibility and } \\
\text { flexibility in } \\
\text { arrangements to deal } \\
\text { with unexpected } \\
\text { situations }\end{array}$ & $\begin{array}{l}\text { Planning information, } \\
\text { joint improvement }\end{array}$ & $\begin{array}{l}\text { Firm performance: costs } \\
\text { to serve the key buyer, } \\
\text { response to key buyer } \\
\text { requirements }\end{array}$ & $\begin{array}{l}\text { Cooperative behaviour } \rightarrow \text { planning } \\
\text { information } \\
\text { Cooperative behaviour } \rightarrow \text { joint } \\
\text { improvement } \\
\text { Planning information } \rightarrow \text { performance } \\
\text { Cooperative behaviour } \rightarrow \\
\text { performance }\end{array}$ & \\
\hline $\begin{array}{l}\text { Whipple and } \\
\text { Russell (2007) }\end{array}$ & $\begin{array}{l}\text { Grounded theory } \\
\text { approach }\end{array}$ & $\begin{array}{l}\text { Collab. transaction } \\
\text { management and } \\
\text { collab. event } \\
\text { management: "based } \\
\text { on trust" } \\
\text { Collab. process } \\
\text { management: } \\
\text { commitment which } \\
\text { leads to "high levels } \\
\text { of trust" }\end{array}$ & $\begin{array}{l}\text { Three types of } \\
\text { collaborative approaches } \\
\text { are identified. The model } \\
\text { does not explicitly } \\
\text { examine supply chain } \\
\text { integration }\end{array}$ & $\begin{array}{l}\text { No specific metrics are } \\
\text { examined }\end{array}$ & $\begin{array}{l}\text { Collab. transaction mgmt: higher SC } \\
\text { visibility } \rightarrow \text { cost reduction, improved } \\
\text { in-stock performance } \\
\text { Collab. event mgmt: joint-planning } \\
\text { and decision-making } \rightarrow \text { higher } \\
\text { forecast accuracy, lower safety stock } \\
\text { levels, improved in-stock levels, } \\
\text { higher cross-functional integration } \\
\text { Collab. process mgmt: increased } \\
\text { sales growth, improved fill rate, } \\
\text { enhanced event execution, improved } \\
\text { inventory turns, reduced out-of-stock }\end{array}$ & $\begin{array}{l}\text { Semi-structured } \\
\text { interviews / no extensive } \\
\text { survey and model } \\
\text { validation }\end{array}$ \\
\hline Wu et al (2004) & $\begin{array}{l}\text { Review of relevant } \\
\text { SCM literature }\end{array}$ & $\begin{array}{l}\text { Continuity } \\
\text { Communication } \\
\text { Power } \\
\text { Trust } \\
\text { SCM commitment }\end{array}$ & $\begin{array}{l}\text { Customer relationship } \\
\text { management } \\
\text { Demand management } \\
\text { New product development }\end{array}$ & $\underline{\mathrm{N} / \mathrm{A}}$ & $\begin{array}{l}\text { Sufficient support } \\
\text { Behavioural determinants of SCM } \rightarrow \\
\text { SCM commitment } \\
\text { Partial support } \\
\text { SCM commitment } \rightarrow \text { integration of } \\
\text { business processes } \\
\text { Behavioural determinants } \rightarrow \\
\text { integration of business processes }\end{array}$ & $\begin{array}{l}\text { Also studies impact of } \\
\text { marketing determinants of } \\
\text { SCM on SCM } \\
\text { commitment and business } \\
\text { integration }\end{array}$ \\
\hline $\begin{array}{l}\text { Xiao et al } \\
(2010)\end{array}$ & $\begin{array}{l}\text { Review of relevant } \\
\text { SCM literature }\end{array}$ & $\begin{array}{l}\text { Trust (team / } \\
\text { individual) } \\
\text { Relationship } \\
\text { commitment }\end{array}$ & $\begin{array}{l}\text { The model does not } \\
\text { examine supply chain } \\
\text { integration }\end{array}$ & $\begin{array}{l}\text { Cooperative performance: } \\
\text { customer satisfaction, } \\
\text { cost, earning capacity, } \\
\text { relationship continuance, } \\
\text { target reaching rate, profit } \\
\text { rate, growth rate of net } \\
\text { profit }\end{array}$ & $\begin{array}{l}\text { Trust } \rightarrow \text { relationship commitment } \\
\text { Trust } \rightarrow \text { cooperative performance } \\
\text { Relationship commitment } \rightarrow \\
\text { cooperative performance }\end{array}$ & \\
\hline
\end{tabular}




\begin{tabular}{|c|c|c|c|c|c|c|}
\hline Reference & $\begin{array}{l}\text { Theoretical context } \\
\text { / background }\end{array}$ & Behavioural factors & $\begin{array}{l}\text { Cooperation/integration } \\
\text { dimensions }\end{array}$ & $\begin{array}{l}\text { Performance dimensions / } \\
\text { metrics }\end{array}$ & Results (hypotheses supported) & Comments \\
\hline $\begin{array}{l}\text { Zacharia et al } \\
\text { (2009) }\end{array}$ & $\begin{array}{l}\text { Resource-based } \\
\text { view theory, } \\
\text { relational view } \\
\text { theory }\end{array}$ & $\begin{array}{l}\text { Relational outcomes: } \\
\text { respect for partner's } \\
\text { capabilities, honesty, } \\
\text { open sharing of info, } \\
\text { commitment to work } \\
\text { together in future, } \\
\text { partnership and } \\
\text { solidarity }\end{array}$ & $\begin{array}{l}\text { Collaborative planning } \\
\text { Joint decisions } \\
\text { Joint goal setting } \\
\text { Meetings } \\
\text { Information sharing }\end{array}$ & $\begin{array}{l}\text { Operational outcomes: } \\
\text { costs, quality, customer } \\
\text { service, project results, } \\
\text { cycle time/lead time, } \\
\text { safety / environmental / } \\
\text { regulatory performance, } \\
\text { value to customers } \\
\text { Business performance: } \\
\text { overall organizational } \\
\text { performance, asset } \\
\text { utilization, competitive } \\
\text { position, profitability }\end{array}$ & $\begin{array}{l}\text { Collaboration level } \rightarrow \text { operational } \\
\text { outcomes } \\
\text { Collaboration level } \rightarrow \text { relational } \\
\text { outcomes } \\
\text { Oper. outcomes } \rightarrow \text { bus. perf. } \\
\text { Relational outcomes } \rightarrow \text { bus. perf. }\end{array}$ & $\begin{array}{l}\text { Operational and relational } \\
\text { outcomes are results of } \\
\text { the level of collaboration } \\
\text { and in turn improve } \\
\text { business performance }\end{array}$ \\
\hline
\end{tabular}


Table 2. Classification of supply chain relationships in terms of major distinguishing characteristics of different forms of exchange (after Ring and van de Ven, 1992)

\begin{tabular}{|c|c|c|c|c|c|}
\hline $\begin{array}{l}\text { Forms of exchange } \\
\text { Characteristics }\end{array}$ & $\begin{array}{l}\text { Discrete market } \\
\text { transactions }\end{array}$ & $\begin{array}{l}\text { Hierarchical managerial } \\
\text { transactions }\end{array}$ & $\begin{array}{l}\text { Recurrent contracting } \\
\text { transactions }\end{array}$ & $\begin{array}{l}\text { Relational contracting } \\
\text { transactions }\end{array}$ & $\begin{array}{l}\text { Supply chain } \\
\text { relationships }\end{array}$ \\
\hline Nature of exchange & $\begin{array}{l}\text { One-time transfer of } \\
\text { property rights }\end{array}$ & $\begin{array}{l}\text { Ongoing production and } \\
\text { rationing of wealth }\end{array}$ & $\begin{array}{l}\text { Episodic production and } \\
\text { transfer of property } \\
\text { rights }\end{array}$ & $\begin{array}{l}\text { Sustained production } \\
\text { and transfer of property } \\
\text { rights }\end{array}$ & $\begin{array}{l}\text { Sustained production } \\
\text { and transfer of property } \\
\text { rights }\end{array}$ \\
\hline Terms of exchange & $\begin{array}{l}\text { Clear, complete and } \\
\text { monetized, sharp in by } \\
\text { agreement, sharp out by } \\
\text { pay and performance }\end{array}$ & $\begin{array}{l}\text { Authority structure } \\
\text { superior hires, } \\
\text { subordinate obeys or } \\
\text { quits the employment } \\
\text { relationship }\end{array}$ & $\begin{array}{l}\text { Certain, complete and } \\
\text { contingent on prior } \\
\text { performance; plans for } \\
\text { experimentation on } \\
\text { safeguards }\end{array}$ & $\begin{array}{l}\text { Uncertain, open and } \\
\text { incomplete; plans for } \\
\text { bilateral learning } \\
\text { safeguards and conflict } \\
\text { resolution }\end{array}$ & $\begin{array}{l}\text { Certain, complete and } \\
\text { contingent on prior } \\
\text { performance }\end{array}$ \\
\hline $\begin{array}{l}\text { Transaction-specific } \\
\text { investment }\end{array}$ & Nonspecific & Idiosyncratic & Mixed & Mixed and idiosyncratic & Mixed and idiosyncratic \\
\hline $\begin{array}{l}\text { Temporal duration of the } \\
\text { transaction }\end{array}$ & Simultaneous exchange & Indefinite & Short to moderate term & Moderate to long term & Long-term \\
\hline Status of the parties & $\begin{array}{l}\text { Limited, non-unique } \\
\text { relation between legally } \\
\text { equal and free parties }\end{array}$ & $\begin{array}{l}\text { Structural functional } \\
\text { command-obedience } \\
\text { role relationship } \\
\text { between legally unequal } \\
\text { parties }\end{array}$ & $\begin{array}{l}\text { Unlimited, unique } \\
\text { relation between free } \\
\text { and legally equal parties }\end{array}$ & $\begin{array}{l}\text { Extensive, unique } \\
\text { social-embedded } \\
\text { relation between legally } \\
\text { equal, and free parties }\end{array}$ & $\begin{array}{l}\text { Social-embedded } \\
\text { relations between } \\
\text { legally equal, and free } \\
\text { parties }\end{array}$ \\
\hline $\begin{array}{l}\text { Mechanisms for dispute } \\
\text { resolution }\end{array}$ & $\begin{array}{l}\text { External market norms } \\
\text { and societal legal } \\
\text { system }\end{array}$ & $\begin{array}{l}\text { Internal conflict } \\
\text { resolution by fiat and } \\
\text { authority }\end{array}$ & $\begin{array}{l}\text { Norms of equity and of } \\
\text { reciprocity and societal } \\
\text { legal systems }\end{array}$ & $\begin{array}{l}\text { Endogenous designed } \\
\text { by the parties and based } \\
\text { on trust }\end{array}$ & $\begin{array}{l}\text { Endogenous designed } \\
\text { by the parties and based } \\
\text { on trust }\end{array}$ \\
\hline $\begin{array}{l}\text { Relevant contract law and } \\
\text { governance structure }\end{array}$ & $\begin{array}{l}\text { Classical contract - } \\
\text { market governance }\end{array}$ & $\begin{array}{l}\text { Employment contract - } \\
\text { unified governance }\end{array}$ & $\begin{array}{l}\text { Neoclassical contract - } \\
\text { market governance }\end{array}$ & $\begin{array}{l}\text { Relational contracts - } \\
\text { bilateral governance }\end{array}$ & $\begin{array}{l}\text { Relational contracts - } \\
\text { bilateral governance }\end{array}$ \\
\hline
\end{tabular}


Table 3. Supply chain integration dimensions and variables

\begin{tabular}{|l|l|l|}
\hline Dimensions & Variables & Definitions \\
\hline \multirow{4}{*}{$\begin{array}{l}\text { Information } \\
\text { integration }\end{array}$} & Information visibility & $\begin{array}{l}\text { The ability of supply chain partners to access information } \\
\text { related to operations of the entire supply chain, besides the } \\
\text { activities in which they participate }\end{array}$ \\
\cline { 2 - 3 } & Information timeliness & $\begin{array}{l}\text { The extent to which the abovementioned information is } \\
\text { shared in a timely manner among supply chain partners }\end{array}$ \\
\hline \multirow{5}{*}{$\begin{array}{l}\text { Coordination } \\
\text { of operational } \\
\text { decisions }\end{array}$} & $\begin{array}{l}\text { Coordination of demand } \\
\text { management }\end{array}$ & $\begin{array}{l}\text { Coordination among supply chain partners in the decision- } \\
\text { making process for demand forecasting, inventory } \\
\text { management and replenishment (i.e., when and by how much } \\
\text { to replenish inventory) and determination of customer service } \\
\text { levels }\end{array}$ \\
\cline { 2 - 3 } & $\begin{array}{l}\text { Coordination of resource } \\
\text { planning }\end{array}$ & $\begin{array}{l}\text { Coordination among supply chain partners in the } \\
\text { development and update of the sales and operations plan, and } \\
\text { the decisions on production volume and mix. }\end{array}$ \\
\cline { 2 - 3 } & $\begin{array}{l}\text { Coordination among partners in supply chain event } \\
\text { management, performance assessment and collaborative } \\
\text { replenishment planning. }\end{array}$ \\
\cline { 2 - 3 } & $\begin{array}{l}\text { Coordination of materials } \\
\text { planning }\end{array}$ & $\begin{array}{l}\text { Coordination among supply chain partners in the planning of } \\
\text { material requirements issues (lot sizing, safety stock levels, } \\
\text { safety lead times and demand for service parts). }\end{array}$ \\
\cline { 2 - 3 } & $\begin{array}{l}\text { Coordination of capacity } \\
\text { planning }\end{array}$ & $\begin{array}{l}\text { Coordination among supply chain partners in the decision- } \\
\text { making process for the capacity requirements planning and } \\
\text { capacity allocation across supply chain partners. }\end{array}$ \\
\hline
\end{tabular}


Table 4. Supply chain performance dimensions and metrics

\begin{tabular}{|l|l|l|l|}
\hline Dimensions & Metrics & Definitions & Indicative references \\
\hline \multirow{5}{*}{ Efficiency } & $\begin{array}{l}\text { Supply chain cycle } \\
\text { efficiency }\end{array}$ & $\begin{array}{l}\text { Ratio of time in which inventory (i.e., } \\
\text { raw materials / WIP / finished products) } \\
\text { is active/moving in the supply chain over } \\
\text { total time spent in the supply chain }\end{array}$ & $\begin{array}{l}\text { Brewer and Speh (2000); Gunasekaran, } \\
\text { Patel and Tirtiroglu (2001) (after "efficiency } \\
\text { of purchase order cycle time") }\end{array}$ \\
\cline { 2 - 5 } Effectiveness & $\begin{array}{l}\text { Supply chain } \\
\text { flexibility }\end{array}$ & $\begin{array}{l}\text { Average time required for the supply } \\
\text { chain to respond to an unplanned 20\% } \\
\text { increase in demand without service or } \\
\text { cost penalty }\end{array}$ & $\begin{array}{l}\text { Shepherd and Günther (2006); Supply Chain } \\
\text { Council (2010) }\end{array}$ \\
\hline \multirow{nyyy}{*}{$\begin{array}{l}\text { Order fulfilment } \\
\text { lead-time }\end{array}$} & $\begin{array}{l}\text { Average time between order entry and } \\
\text { time of order delivery }\end{array}$ & $\begin{array}{l}\text { Gunasekaran, Patel and Tirtiroglu (2001); } \\
\text { Shepherd and Günther (2006); Supply Chain } \\
\text { Council (2010) }\end{array}$ \\
\cline { 2 - 5 } & $\begin{array}{l}\text { Perfect order } \\
\text { fulfilment }\end{array}$ & $\begin{array}{l}\text { Ratio of orders delivered i) complete, ii) } \\
\text { on the date requested by the customer, iii) } \\
\text { in perfect condition, iv) with the correct } \\
\text { documentation over total number of } \\
\text { orders }\end{array}$ & $\begin{array}{l}\text { Croxton (2003); Shepherd and Günther } \\
\text { (2006); Supply Chain Council (2010) }\end{array}$ \\
\hline
\end{tabular}


Table 5. Items included in survey instrument

\begin{tabular}{|c|c|c|c|c|}
\hline Constructs & Dimensions & Variables & Measurement item & Scale used \\
\hline \multirow{20}{*}{$\begin{array}{l}\text { Behavioural } \\
\text { antecedents } \\
\text { of supply } \\
\text { chain } \\
\text { integration }\end{array}$} & & $\begin{array}{l}\text { Question } \\
\text { asked }\end{array}$ & $\begin{array}{l}\text { On a scale from } 1 \text { to } 5 \text {, please assess the degree to which you agree with each statement concerning the } \\
\text { relationship of your company with its major supplier / major customer in the supply chain under examination }\end{array}$ & \\
\hline & \multirow{7}{*}{ Trust } & \multirow{4}{*}{ Credibility } & Both our company and the major customer /supplier are frank when doing business with each other & \multirow{19}{*}{$\begin{array}{l}1=\text { strongly disagree } \\
2=\text { somewhat } \\
\text { disagree, } \\
3=\text { neither disagree } \\
\text { nor agree, } \\
4=\text { somewhat agree, } \\
5=\text { strongly agree }\end{array}$} \\
\hline & & & Promises (e.g., delivery dates, order placements etc.) made by the major customer /supplier are not reliable & \\
\hline & & & If problems arise in the relationship, our company and the major customer/supplier are honest about them & \\
\hline & & & We feel that our major customer/supplier will not let us down & \\
\hline & & \multirow{3}{*}{ Benevolence } & $\begin{array}{l}\text { In the past, both our company and the major customer /supplier have made sacrifices for the sake of preserving the } \\
\text { relationship }\end{array}$ & \\
\hline & & & Both our company and our major customer /supplier care for the well-being of this relationship & \\
\hline & & & If problems arise in the relationship, our major customer/supplier is not understanding & \\
\hline & \multirow{7}{*}{ Commitment } & \multirow{3}{*}{$\begin{array}{l}\text { Affective } \\
\text { commitment }\end{array}$} & $\begin{array}{l}\text { A strong sense of belonging in this relationship does not exist neither for our company nor for the major customer } \\
\text { /supplier }\end{array}$ & \\
\hline & & & $\begin{array}{l}\text { If needed, both our company and the major customer /supplier could become as easily attached to a relationship with } \\
\text { another similar partner as they are in the current relationship }\end{array}$ & \\
\hline & & & Our company and the major customer /supplier have a strong emotional attachment to this relationship & \\
\hline & & \multirow{4}{*}{$\begin{array}{l}\text { Continuance } \\
\text { commitment }\end{array}$} & $\begin{array}{l}\text { It would be very hard for our company or the major customer /supplier to leave this relationship right now, even if } \\
\text { they wanted to }\end{array}$ & \\
\hline & & & It would not be too costly for our company or the major customer /supplier to leave this relationship now & \\
\hline & & & $\begin{array}{l}\text { Right now, maintaining this relationship is a matter of necessity as much as desire for our company and the major } \\
\text { customer /supplier }\end{array}$ & \\
\hline & & & $\begin{array}{l}\text { A serious consequence of our company or the major customer /supplier leaving this relationship would be the } \\
\text { scarcity of available alternatives for our company }\end{array}$ & \\
\hline & \multirow{5}{*}{ Mutuality } & \multirow[b]{2}{*}{$\begin{array}{l}\text { Distributive } \\
\text { justice }\end{array}$} & Both our company and the major customer /supplier want this relationship to be mutually profitable & \\
\hline & & & $\begin{array}{l}\text { Both our company and the major customer /supplier are convinced that the concessions they make will be } \\
\text { compensated for in the long run }\end{array}$ & \\
\hline & & \multirow{2}{*}{$\begin{array}{l}\text { Procedural } \\
\text { justice }\end{array}$} & $\begin{array}{l}\text { Our company and the major customer /supplier try to explain to each other their decisions that concern the business } \\
\text { within their relationship }\end{array}$ & \\
\hline & & & In negotiations, our company and the major customer /supplier always show a fair behavior & \\
\hline & & $\begin{array}{l}\text { Interactional } \\
\text { justice }\end{array}$ & $\begin{array}{l}\text { In this relationship, both our company and the major customer /supplier always treat each other the way they expect } \\
\text { to be treated }\end{array}$ & \\
\hline
\end{tabular}




\begin{tabular}{|c|c|c|c|c|}
\hline Constructs & Dimensions & Variables & Measurement item & Scale used \\
\hline & & & In this relationship, both our company and the major customer/supplier treat each other with respect & \\
\hline & \multirow{5}{*}{ Reciprocity } & \multirow{2}{*}{$\begin{array}{l}\text { Equality of } \\
\text { obligations }\end{array}$} & $\begin{array}{l}\text { In this relationship, both our company and the major customer /supplier feel that they do not undertake more or less } \\
\text { obligations than the other }\end{array}$ & \\
\hline & & & $\begin{array}{l}\text { Both our company and the major customer /supplier are comfortable in undertaking the amount of obligations } \\
\text { brought about by this relationship }\end{array}$ & \\
\hline & & \multirow{2}{*}{$\begin{array}{l}\text { Equality of } \\
\text { fulfilment of } \\
\text { obligations }\end{array}$} & $\begin{array}{l}\text { The distribution of the outcome of this relationship (whether positive or negative) is fair both for our company and } \\
\text { the major customer /supplier }\end{array}$ & \\
\hline & & & $\begin{array}{l}\text { Long-term benefits from entering such a relationship do not outweigh the disadvantages that both our company and } \\
\text { the major customer /supplier bear from entering this relationship }\end{array}$ & \\
\hline & & $\begin{array}{l}\text { Equality of } \\
\text { support among } \\
\text { partners }\end{array}$ & In this relationship, our company provides as much support to its major customer /supplier as vice versa & \\
\hline \multirow{14}{*}{$\begin{array}{l}\text { Supply } \\
\text { chain } \\
\text { integration }\end{array}$} & & $\begin{array}{l}\text { Question } \\
\text { asked }\end{array}$ & $\begin{array}{l}\text { On a scale from } 1 \text { to } 5 \text {, please rate how you perceive the score of your supply chain in terms of the following } \\
\text { dimensions measuring supply chain integration }\end{array}$ & \\
\hline & \multirow{10}{*}{$\begin{array}{l}\text { Information } \\
\text { integration }\end{array}$} & \multirow{5}{*}{$\begin{array}{l}\text { Information } \\
\text { visibility }\end{array}$} & Visibility of demand management information with major customer / major supplier & \multirow{5}{*}{$\begin{array}{l}1=\text { information } \\
\text { visible only to your } \\
\text { company } \\
2=\text { slight visibility } \\
3=\text { moderate } \\
\text { visibility } \\
4=\text { substantial } \\
\text { visibility } \\
5=\text { complete } \\
\text { visibility }\end{array}$} \\
\hline & & & Visibility of sales and operation planning information with major customer / major supplier & \\
\hline & & & Visibility of resource planning information with major customer / major supplier & \\
\hline & & & Visibility of materials planning information with major customer / major supplier & \\
\hline & & & Visibility of capacity planning information with major customer / major supplier & \\
\hline & & & Timeliness of sharing demand management information with major customer / major supplier & $1=$ no sharing \\
\hline & & & Timeliness of sharing sales and operation planning information with major customer / major supplier & $2=$ delayed sharing \\
\hline & & Information & Timeliness of sharing resource planning information with major customer / major supplier & $3=$ neither delayed \\
\hline & & timeliness & Timeliness of sharing materials planning information with major customer / major supplier & nor fast sharing \\
\hline & & & Timeliness of sharing capacity planning information with major customer / major supplier & $\begin{array}{l}4=\text { fast sharing } \\
5=\text { immediate sharing }\end{array}$ \\
\hline & Coordination & Coordination & Joint coordination of forecasting of demand with major customer / major supplier & $1=$ no coordination \\
\hline & of operational & of demand & Joint coordination of determination of safety stock levels with major customer / major supplier & $2=$ slight \\
\hline & decisions & management & Joint coordination of determination of replenishment frequencies with major customer / major supplier & coordination \\
\hline
\end{tabular}




\begin{tabular}{|c|c|c|c|c|}
\hline Constructs & Dimensions & Variables & Measurement item & Scale used \\
\hline & & & Joint coordination of determination of desired customer service levels with major customer / major supplier & \multirow{11}{*}{$\begin{array}{l}3=\text { moderate } \\
\text { coordination } \\
4=\text { high coordination } \\
5=\text { complete } \\
\text { coordination }\end{array}$} \\
\hline & & \multirow{2}{*}{$\begin{array}{l}\text { Coordination } \\
\text { of sales and } \\
\text { operations } \\
\text { planning }\end{array}$} & Joint coordination of development and update of sales and operations plan with major customer / major supplier & \\
\hline & & & Joint coordination of decisions on product volume and mix with major customer / major supplier & \\
\hline & & \multirow{3}{*}{$\begin{array}{l}\text { Coordination } \\
\text { of resource } \\
\text { planning }\end{array}$} & Joint coordination of supply chain event management with major customer / major supplier & \\
\hline & & & Joint coordination of supply chain performance assessment with major customer / major supplier & \\
\hline & & & Joint coordination of collaborative replenishment planning with major customer / major supplier & \\
\hline & & \multirow{3}{*}{$\begin{array}{l}\text { Coordination } \\
\text { of materials } \\
\text { planning }\end{array}$} & Joint coordination of determination of lot sizes with major customer / major supplier & \\
\hline & & & Joint coordination of determination of safety lead times with major customer / major supplier & \\
\hline & & & Joint coordination of determination of the demand for service parts with major customer / major supplier & \\
\hline & & \multirow{2}{*}{$\begin{array}{l}\text { Coordination } \\
\text { of capacity } \\
\text { planning }\end{array}$} & Joint coordination of production capacity estimation with major customer / major supplier & \\
\hline & & & $\begin{array}{l}\text { Joint coordination of allocating production capacity to confirmed and forecast demand with major customer / major } \\
\text { supplier }\end{array}$ & \\
\hline \multirow{5}{*}{$\begin{array}{l}\text { Supply } \\
\text { chain } \\
\text { performance }\end{array}$} & & $\begin{array}{l}\text { Question } \\
\text { asked }\end{array}$ & $\begin{array}{l}\text { On a scale from } 1 \text { to } 5(1=\text { very low / } 5 \text { = very high }) \text {, please rate how you perceive the performance of your } \\
\text { supply chain in terms of the following metrics }\end{array}$ & \\
\hline & \multirow{2}{*}{ Efficiency } & & $\begin{array}{l}\text { Supply chain cycle efficiency } \\
\text { Definition: Percentage of time in which inventory (raw materials / WIP / finished products) is active/moving in the } \\
\text { supply chain over total time spent in the supply chain }\end{array}$ & \multirow{4}{*}{$\begin{array}{l}1=\text { very low } \\
\text { performance } \\
2=\text { low performance, } \\
3=\text { moderate } \\
\text { performance } \\
4=\text { high performance } \\
5=\text { very high } \\
\text { performance }\end{array}$} \\
\hline & & & $\begin{array}{l}\text { Supply chain flexibility } \\
\text { Definition: Average time required for the supply chain to respond to an unplanned } 20 \% \text { increase in demand without } \\
\text { service or cost penalty }\end{array}$ & \\
\hline & \multirow[b]{2}{*}{ Effectiveness } & & $\begin{array}{l}\text { Order fulfilment lead-time } \\
\text { Definition: Average time between order entry and time of order delivery }\end{array}$ & \\
\hline & & & $\begin{array}{l}\text { Perfect order fulfilment } \\
\text { Definition: Orders delivered i) complete, ii) on the date requested by the customer and iii) in perfect condition and } \\
\text { iv) with the correct documentation, over total number of orders }\end{array}$ & \\
\hline
\end{tabular}

